\title{
Genotypic diversity of Dictyosphaerium-morphospecies (Chlorellaceae, Trebouxiophyceae) in African inland waters, including the description of four new genera
}

\author{
Lothar Krienitz ${ }^{*}$, Christina Bock ${ }^{1,2}$, Kiplagat KotuT ${ }^{3} \&$ Thomas Pröschold $^{4,5}$ \\ ${ }^{1}$ Leibniz-Institute of Freshwater Ecology and Inland Fisheries, Alte Fischerhütte 2, \\ D-16775 Stechlin-Neuglobsow, Germany; *Corresponding author e-mail: krie@igb-berlin.de \\ ${ }^{2}$ University of Essen, Faculty of Biology, D-45141 Essen, Germany \\ ${ }^{3}$ Plant and Microbial Sciences Department of Kenyatta University Nairobi, PO Box 43844 GPO 00100 Nairobi, \\ Kenya \\ ${ }^{4}$ University of Vienna, Department of Limnology, Althanstr. 14, A-1090 Vienna, Austria \\ ${ }^{5}$ University of Rostock, Department of Applied Ecology, Albert-Einstein-Str. 3, D-18059 Rostock, Germany
}

\begin{abstract}
Trebouxiophytes of the Dictyosphaerium-morphotype from inland waters of Africa were studied using a polyphasic approach of SSU and ITS rDNA phylogeny, secondary structure of the ITS and observations made with a light microscope. Although the morphological criteria for differentiating species and genera are scarce, the genetic diversity of these algae was very high. Based on our genetic analysis findings, we described four new genera containing five new species: Compactochlorella dohrmannii, Compactochlorella kochii, Kalenjinia gelatinosa, Marasphaerium gattermannii and Masaia oloidia. Diversity and distribution of Chlorella-related colonial chlorophytes in the tropical and temperate zones were compared and discussed.
\end{abstract}

Key words: Inland waters of Africa, Chlorella, Compactochlorella nov. gen., Dictyosphaerium, diversity, geographic distribution, green algae, Kalenjinia nov. gen., Marasphaerium nov. gen., Masaia nov. gen.

\section{Introduction}

Coccoid green algae are among the most diverse microphytes. In their famous handbook, KOMÁREK \& FotT (1983) compiled more than 1200 taxa. However, these taxa are defined by morphology. To discover the real genotypic diversity of coccoid green algae only few reports with limited progress have been made. For example, Ротter et al. (1997) came up with a thesis of convergent evolution of morphology that masks the extensive biodiversity among coccoid picoplankton. FAWLEY et al. (2004) studied the molecular diversity of coccoid and monadoid green algae in 20 lakes of North America and found 93 distinct SSU rRNA genotypes, 89 of those were new to science. FAWLEY et al. (2005) evaluated the morphospecies concept in Selenastraceae and concluded that numerous cryptic species are hidden by one and the same morphotype. Pröschold \& LeliaerT (2007), Coesel \& Krienitz (2008) and Rindi et al. (2010) discussed the state of the art in diversity and taxonomic conceptions in green algae and recommended studies using a polyphasic approach combining morphological and molecular phylogenetic methods.

Studies about algal biodiversity in Africa have been hampered by several circumstances. For more than 100 years, algae in phytoplankton have been investigated. However, a general limitation of this classical research, especially in the early years is that only fixed samples were taken by scientific travellers and later studied in various laboratories. These findings can be brought into agreement only with difficulties with the today's views over the systematics of algae. The second half of the $20^{\text {th }}$ century saw an increase in the documentation of detailed morphological characteristics leading to the generation of data useful for comparative studies. The most usable findings were published on lakes of the southern and eastern Africa (Huber-Pestalozzi 1929; Talling 1987; CocQuyt et al. 1993). However, the majority of systematic considerations on material from tropical countries are based on identification keys established for temperate zone taxa. Furthermore, investigations 
on living and cultured algal material including sequence analyses are largely missing. Until now, only few cultured strains of coccoid green algae from tropical Africa have been investigated by modern systematic approaches (Luo et al. 2006, 2010; Bock et al. 2010, 2011a; Krienitz \& Bock 2011; KRIENITZ et al. 2010, 2011).

It is widely accepted that microbial diversity differs fundamentally from biodiversity of larger animals and plants (NorTon et al. 1996). Some workers, including Fenchel \& Finlay (2004), have taken up the hypothesis of BAAS-BECKING (1934) based on a metaphor by BEIJERINCK, which suggests that free-living microbes have a cosmopolitan distribution and that most protistan organisms (microalgae and protozoa), smaller than one millimeter in size, have a worldwide distribution wherever their required habitats are realised ("everything is everywhere, but, the environment selects" - see DE Wit \& BouviER 2006). This is a result of their ubiquitous dispersal driven by huge population sizes, and consequently a low probability of local extinction. However, this hypothesis is only based on the phenotypic ("morphospecies") approach and depends on clear identification of the microorganisms. For microalgae, the hypothesis is controversial and remains the subject of ongoing discussions (COLEMAN 2002; Finlay \& FenCHEL 2002; FoISSNER 2006). Further studies, including more isolates from different regions of the world, are needed to prove or reject the hypothesis on the universal dispersal of microalgae.

One of the most common morphotypes of coccoid green algae in the phytoplankton of inland waters is represented by members of the genus Dictyosphaerium. The genus is characterized by green spherical cells interconnected by mucilaginous strands in colonies surrounded by thick gelatinous envelopes (Fig. 1). Although this morphotype has a world-wide distribution, it is difficult to compare findings from different climatic regions. On the base of their morphology, about 11 species are known (KomÁReK \& Perman 1978). The type species Dictyosphaerium ehrenbergianum NäGELI was found in European waters, and closely related morphotypes were also identified as very common in tropical inland waters. Microscopic studies have revealed that in comparison to the phytoplankton from other continents, samples from Africa appear to be especially rich in specimens with thick mucilaginous envelopes. This unusual phenomenon may be a response to water chemistry or the strong interaction with consumer and decomposer populations in the waters studied. The question that remains very contentious is the amount of morphological differences that are necessary to reflect the genotypic diversity of these Dictyosphaeriumlike green algae. Molecular phylogenetic studies have shown that the Dictyosphaeriummorphotype evolved independently in different clades of the Chlorophyta (Bock et al. 2010, 2011b; KRIENITZ et al. 2010, 2011). Out of a collection of 27 chlorellacean strains isolated from different inland waters of Africa, 24 strains belonged to the Dictyosphaerium-morphotype. Based on these strains this study will address the questions (i) how diverse are these coccoid green algae in terms of morphology and phylogeny, and (ii) are the tropical Dictyosphaerium-like algae genotypically identical with those from the temperate climatic region? The outcome of this study is the description of four new genera including five new species.

\section{Material and Methods}

In this study 67 strains belonging to the class Trebouxiophyceae were used (Table 1). Out of 28 African strains, 26 strains were isolated by one of the authors from eight inland waters of Kenya, and one or two waters of Angola, Tanzania, Tunisia, Uganda, and Zambia, respectively. These habitats were of different characteristics. Beside the large Lake Victoria, smaller lakes of the Rift Valley, the lakes Baringo, Naivasha and Oloidien were chosen as sampling area. Other strains were isolated from ephemeral pools in the Ngorongoro Crater in Tanzania, Nakuru National Park in Kenya and from a park pond in Nairobi. We also isolated strains from sewage oxidation ponds, such as the final sewage pond of the Nakuru town sewage plant, and from a sewage pond on the Djerba island in Tunisia. Additional strains were collected in rivers or water channels such as the Mara river in the Masai Mara National Reserve in Kenya, from the Kunene and Okawango in Angola, and from the Kazinga channel in Uganda, which is connected to lakes Albert and George.

We isolated single Chlorella-like cells or colonies of the Dictyosphaerium-morphotype by glass-capillaries from the field samples and transferred them to a liquid medium. All strains were maintained at the strain collection of the 
IGB (Leibniz-Institute of Freshwater Ecology and Inland Fisheries). The strains were grown in a modified Bourrelly medium (Hegewald et al. 1994; KRIENITZ \& WirTH 2006) on agar at 15 ${ }^{\circ} \mathrm{C}$ or in suspensions at room temperature under a $14 \mathrm{~h}: 10 \mathrm{~h}$ light-dark regime. New strains were deposited at the Culture Collection of Algae and Protozoa (CCAP, Oban, UK). The algae were investigated using a Nikon Eclipse E600 light microscope with differential interference contrast. Microphotographs were taken with a Nikon digital camera DS-Fi1, and Nikon software NISElements D (Nikon Corporation, Tokyo, Japan).

In this study, we sequenced the SSU and ITS rRNA gene sequences of 13 strains to establish new sequence data, which were submitted to GenBank. Additionally, 57 sequences from GenBank were included in this data set (Table 1).

Genomic DNA was extracted using a lysozym/sodium phosphate method. The algal cells were mechanical disrupted with glass beads using the TissuelyserII (Qiagen GmbH, Hilden, Germany) in the presence of $600 \mu 1$ sodium phosphate buffer $(120 \mathrm{mM})$ and $100 \mu \mathrm{l}$ SDS $(25 \%)$. After centrifugation for $6 \mathrm{~min}$, the liquid phase was transferred to a clean reaction tube and incubated with $200 \mu 1$ Lysozym at $37^{\circ} \mathrm{C}$ for 1 hour. Afterwards, the probes were incubated at $55^{\circ} \mathrm{C}$ over night after adding $150 \mu \mathrm{l}$ SDS (25\%) and $12.5 \mu \mathrm{l}$ proteinase $\mathrm{K}$. Protein precipitation was done by adding $7.5 \mathrm{M}$ ammonium acetate ( 0.4 times of the existing volume) and incubating on ice for $5 \mathrm{~min}$. The supernatant was transferred to a clean reaction tube after a centrifugation step and DNA was purified with $0.7 \%$ isopropanol and centrifugation for 1 hour. The liquid was discarded and DNA pellet was washed with ethanol (80\%). The SSU and ITS rRNA genes were amplified and sequenced as described by Bock et al. (2011a).

For the phylogenetic analyses, a data set of 68 taxa with 2693 aligned base positions and a dataset with 71 taxa and 2815 bases were used respectively. In order to obtain an adequate representation of chlorellacean algae, different sequences were selected according to Bock et al. (2011a, b) with Catena viridis as outgroup in addition to the newly sequenced strains. The two phylogenetic trees presented in our results were inferred using two different ways of alignment: manual alignment according to the secondary structure; and the ClustalW algorithm integrated in SOAP v.1.2 alpha 4 (LoytynoJA \& MiLinKovitch 2001).
For the first phylogenetic tree, the SSU was manually aligned on the basis of the predicted secondary structure model for Micractinium pusillum (Luo et al. 2006). Stems and loop regions of the $18 \mathrm{~S}$ of the strains were aligned to each other respectively. The ITS regions were more difficult to align due to a high degree of divergence between the sequences. Within this regions, we aligned them strictly according to their predicted secondary structure, e.g. stem regions were aligned separately from loops and unmatching regions. Dubiously aligned regions were excluded. The phylogenetic tree was inferred by maximum likelihood settings on a partitioned data set using Treefinder (JoBB 2008). Models for each partition, as proposed by Treefinder under AICc criterion, were as followed: 18S (J2:G:5 model, 1797 bases), ITS1 (J1:G:5 model, 408 bases), 5.8S (HKY model, 141 bases), ITS2 (GTR:G:5 mode, 347 bases). To test the confidence of the tree topology, bootstrap analyses were calculated by distance (neighbor-joining; NJ; 1000 replicates) and maximum parsimony (MP; 1000 replicates; with heuristic search options based on simple taxon addition, treebisection-reconnection (TBR) branch swapping algorithm and Multrees option enabled) using PAUP*, portable version 4.0b10 (SWOFFORD 2002) and maximum likelihood criteria using Treefinder (ML; 1000 replicates; settings as described above). The Bayesian inference (MB) was calculated using MrBayes version 3.1 (HuelsenbeCK \& RonQuist 2001). Two runs with four chains of Markov chain Monte Carlo (MCMC) iterations were performed with tree sampling every 100 generations. The model GTR $+\mathrm{I}+\mathrm{G}$ with gamma shape parameter and proportion of invariable sites was used for each partition. The parameters were unlinked and allowed to vary across the partitions. The stationary distribution was assumed after 2,000,000 generations when the average standard deviations of split frequencies between two runs were below 0.01 . The first $25 \%$ of the calculated trees were discarded as burn-in. A 50\% majorityrule consensus tree was calculated for posterior probabilities (PP).

For the second phylogenetic tree, the sequences were initially aligned using the ClustalW algorithm integrated in SOAP v.1.2 alpha 4 (Loytynoja \& MilinKovitch 2001). The stability of the alignment was assessed using SOAP by comparison of different ClustalW alignments using gap penalties from 7 to 20 by steps of 2.5 and extension penalties from 2 to 10 by steps 


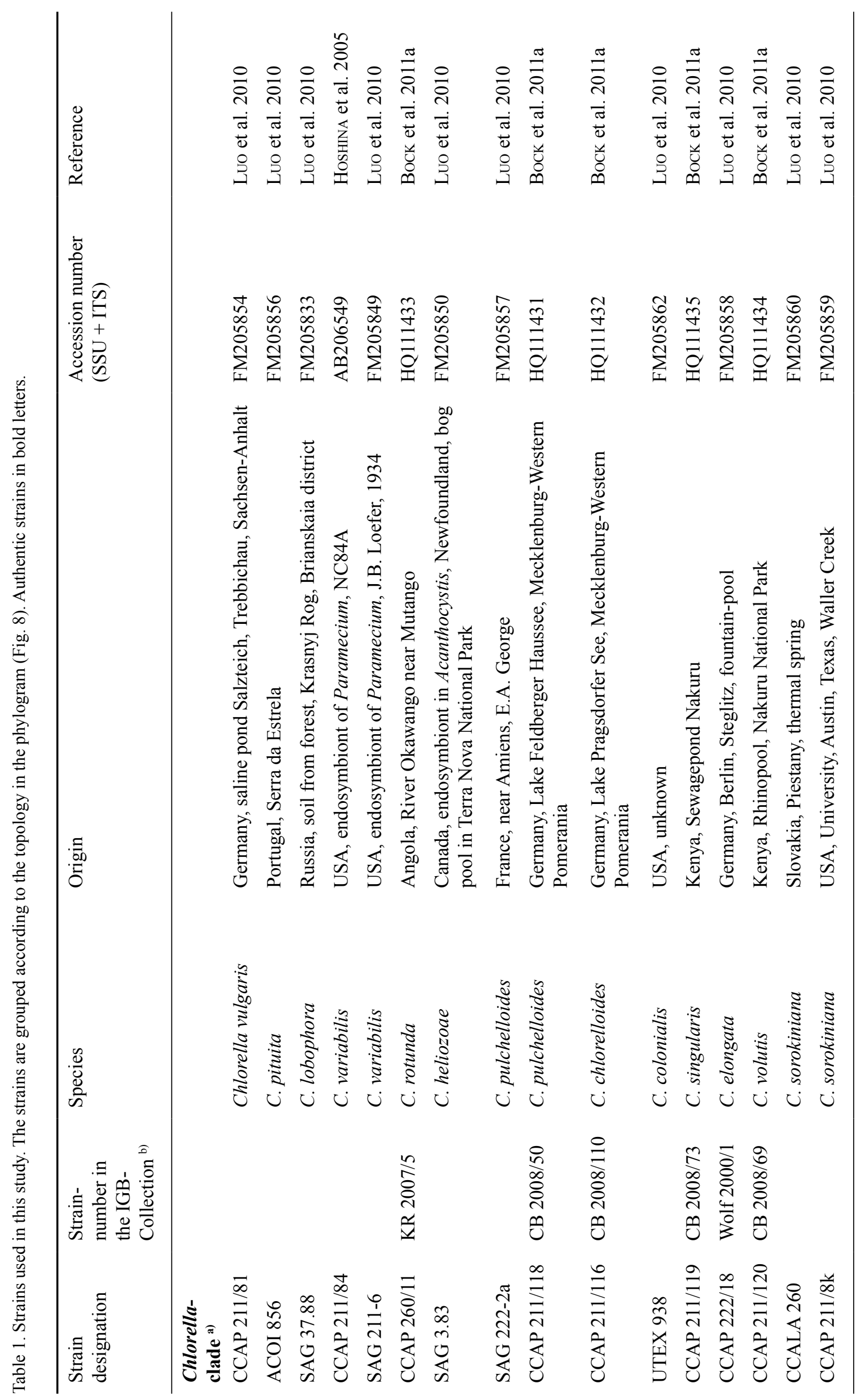




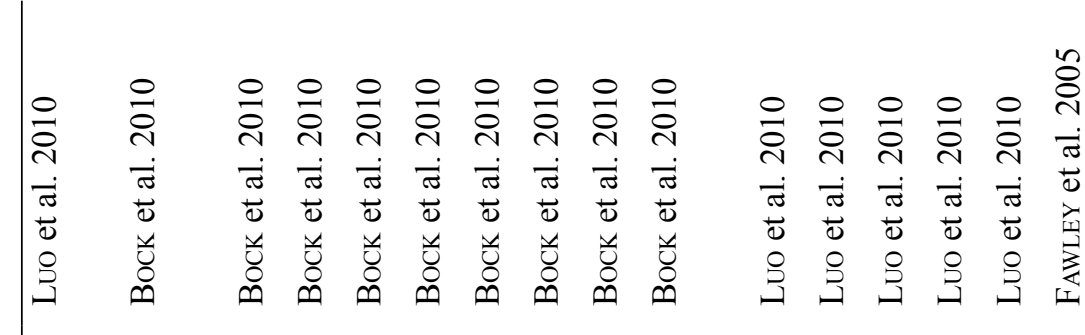

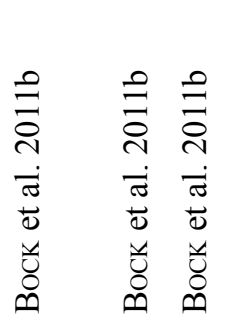

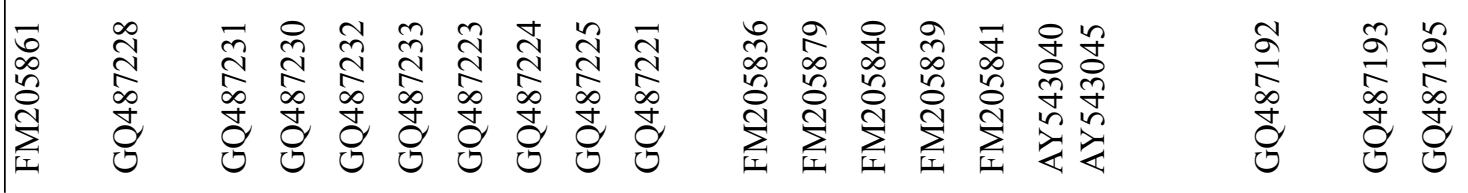

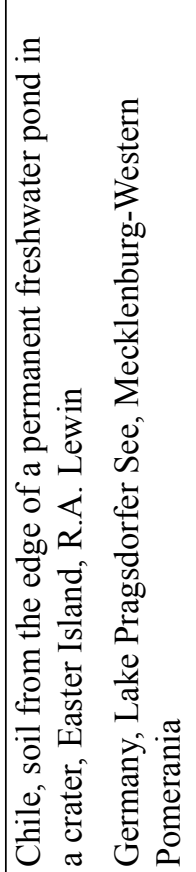

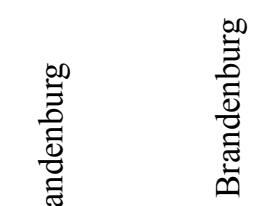

œ

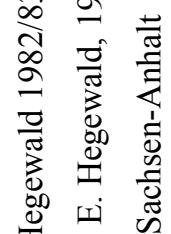

离

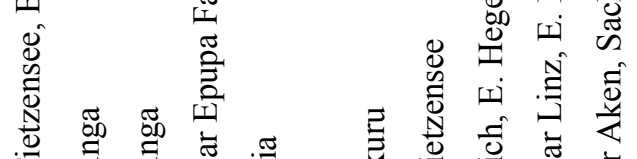

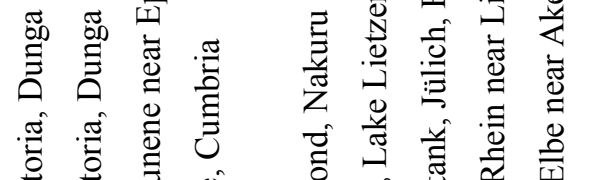

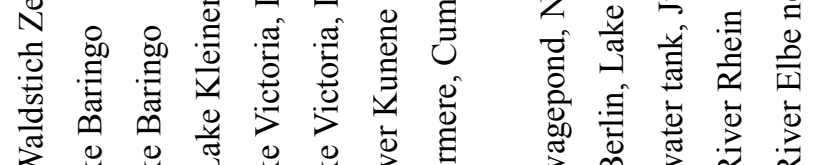

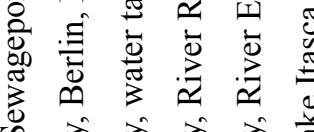

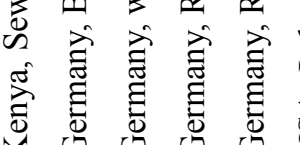

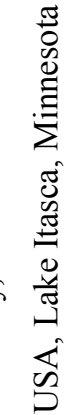

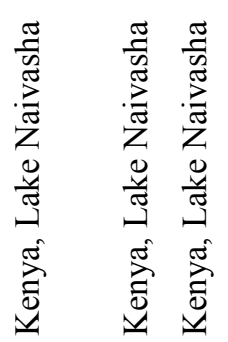

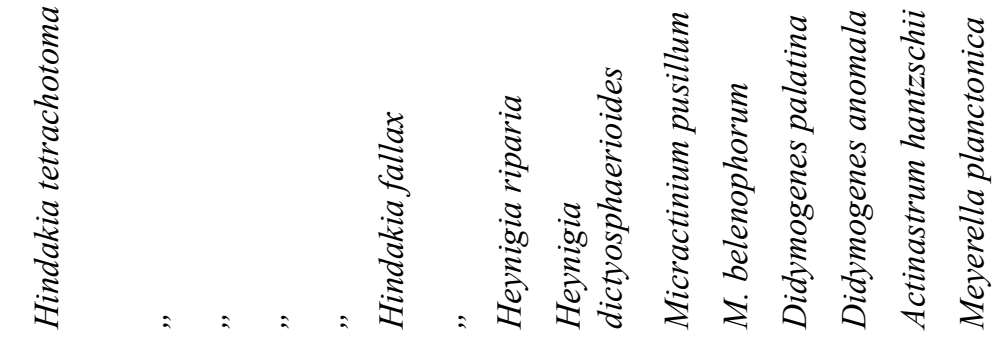

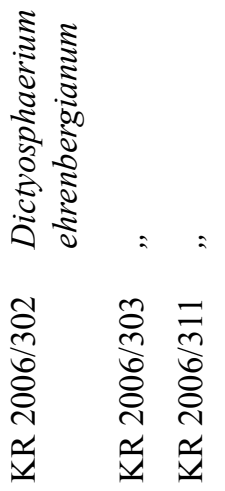

곤

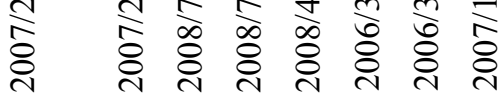

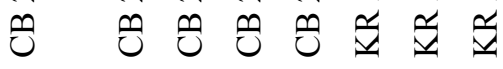

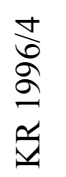

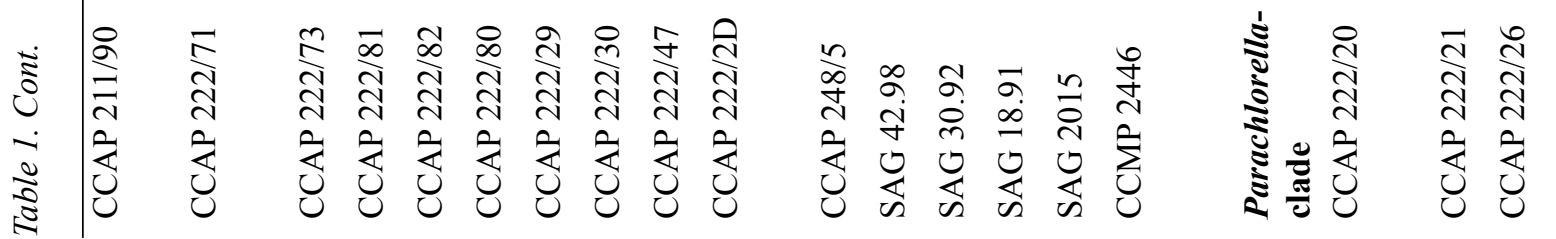




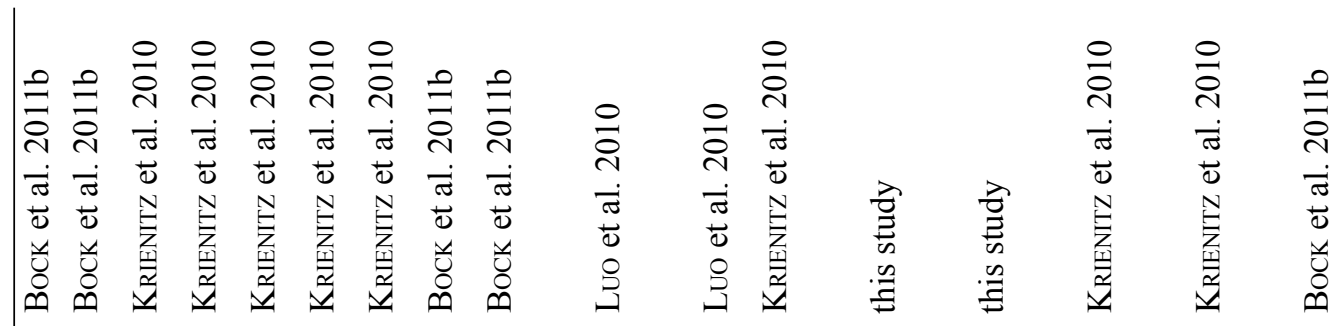

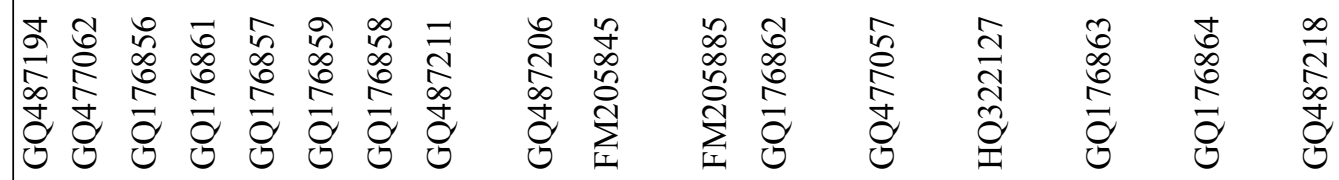

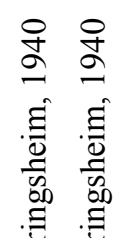

نे

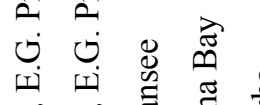

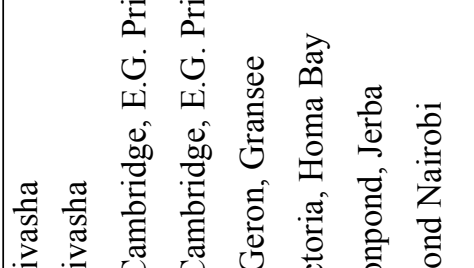

离

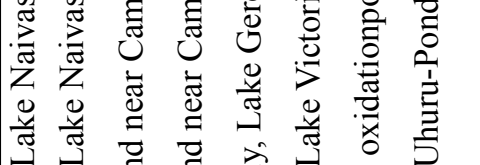

๙ీ.

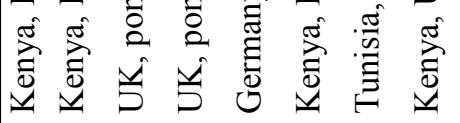
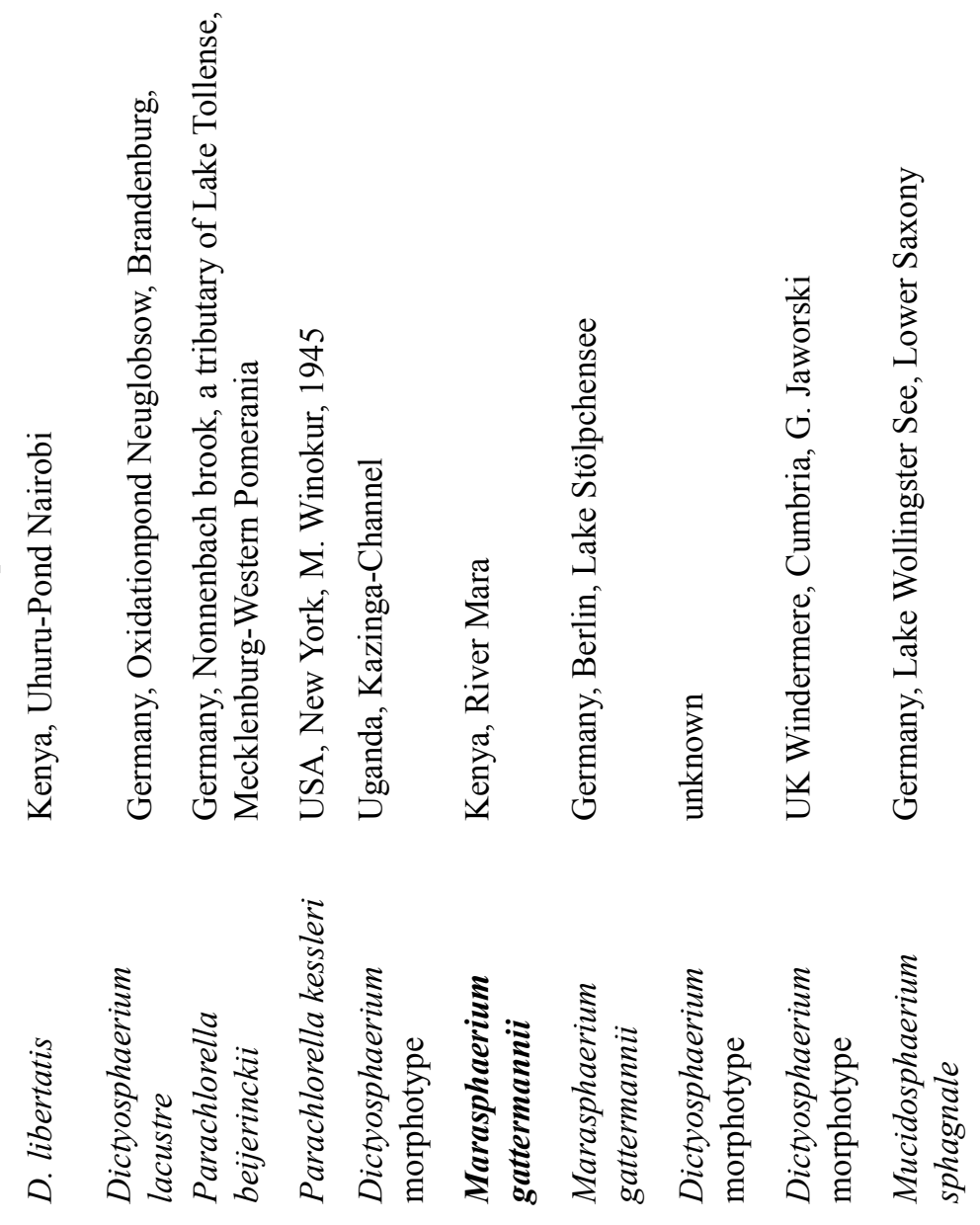

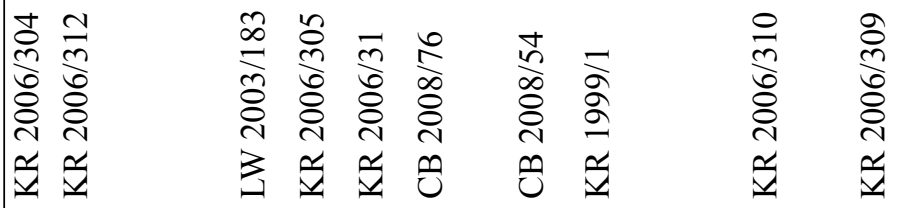

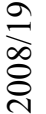

थิ

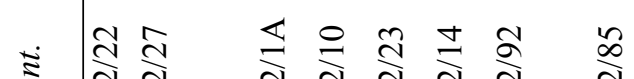

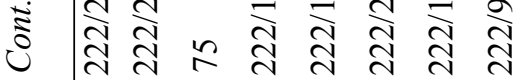

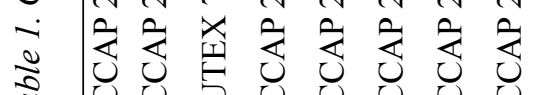

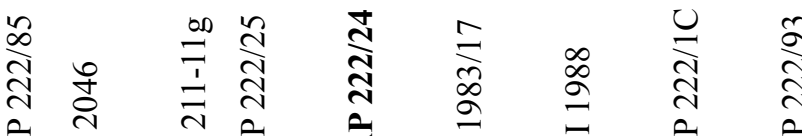

$\approx$

苍芯氙芯 


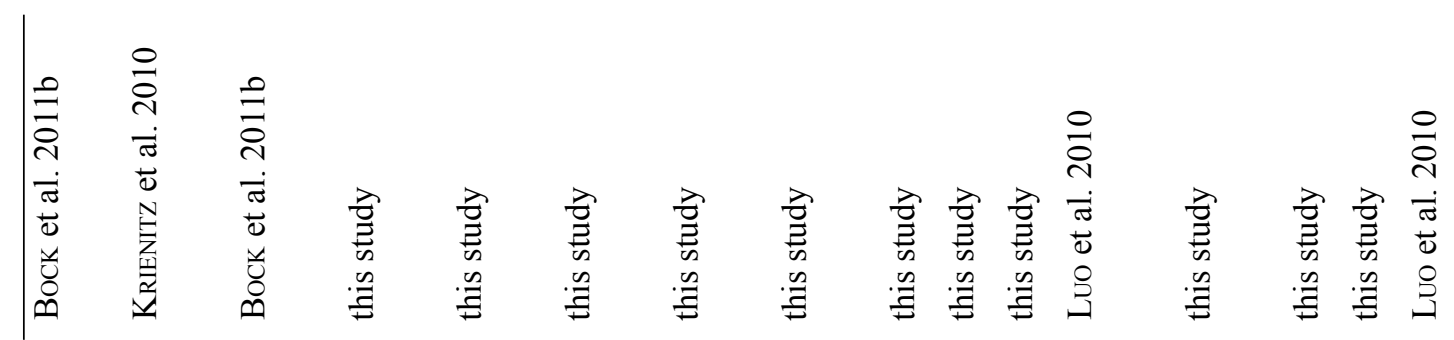

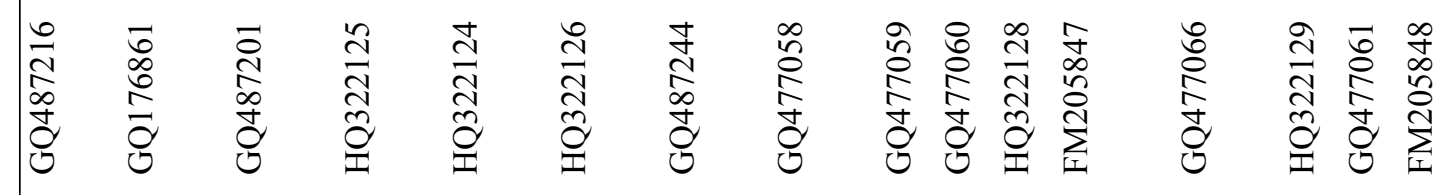

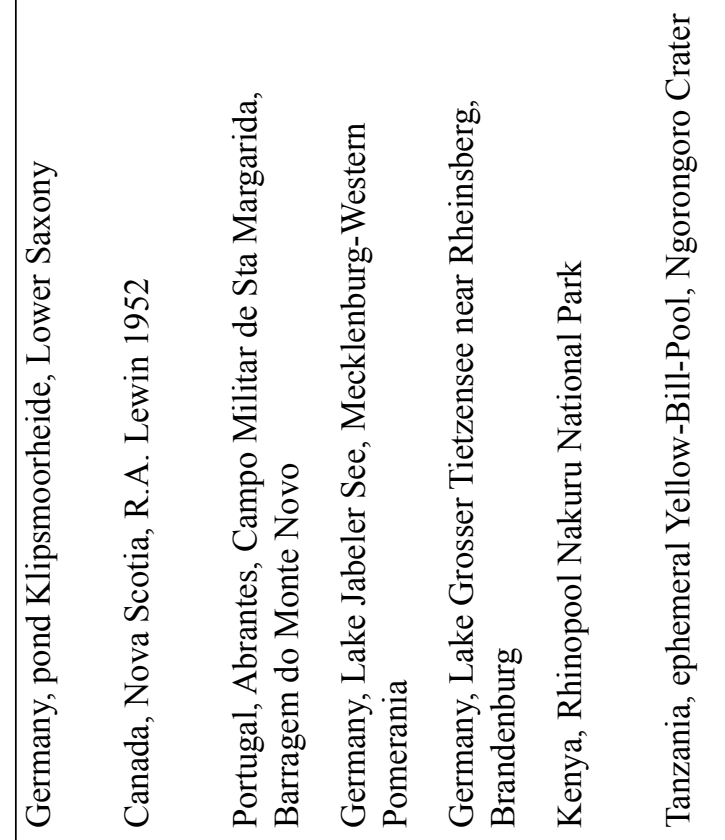

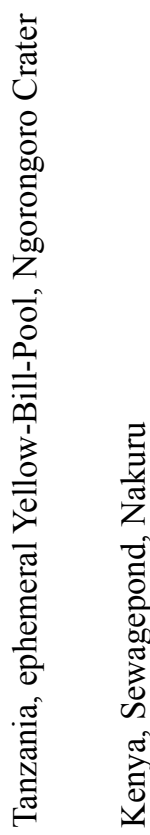

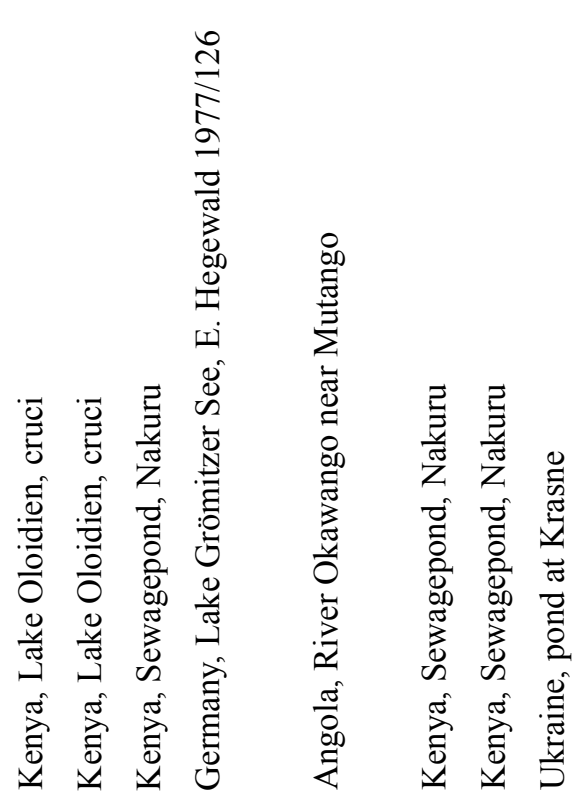

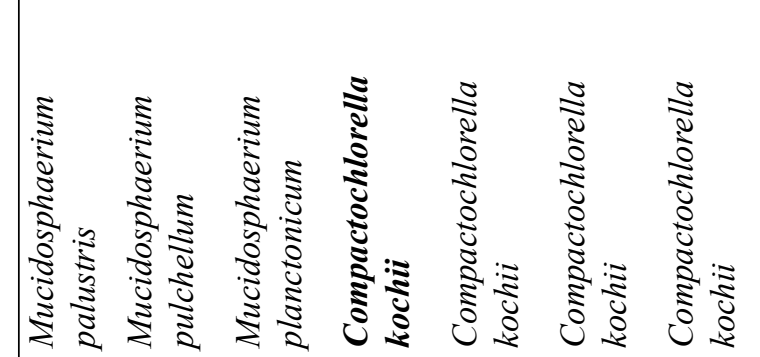
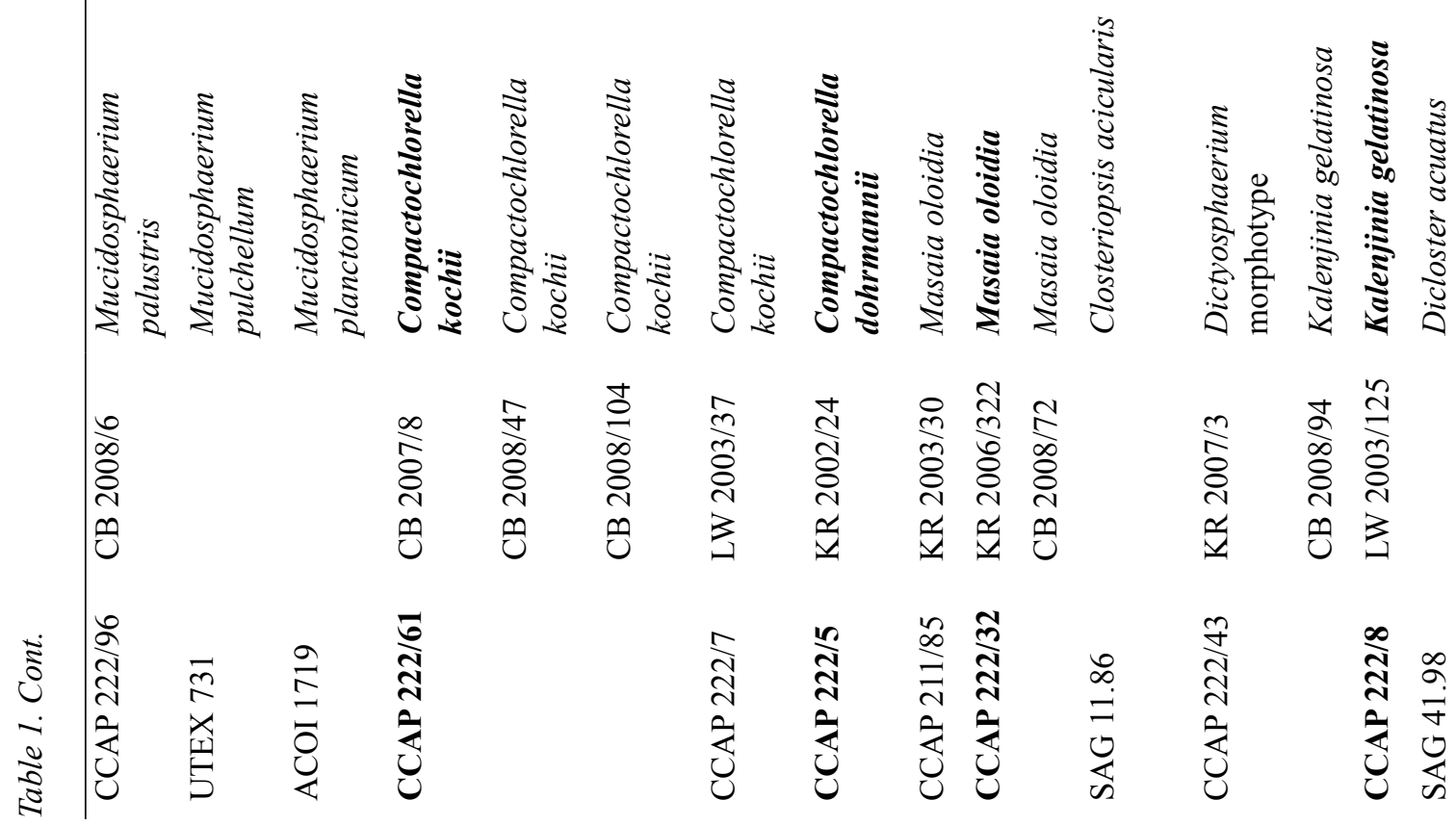

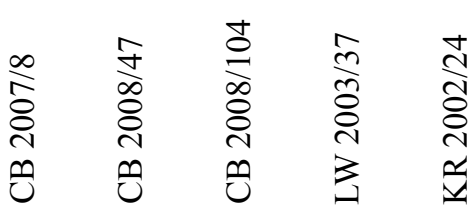

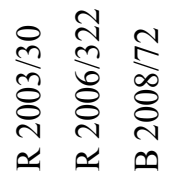

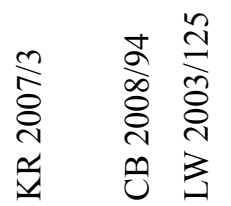

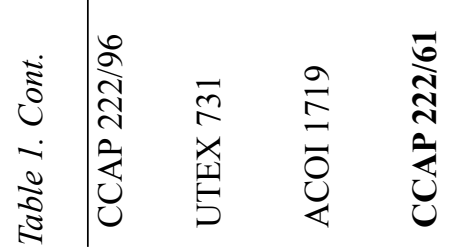

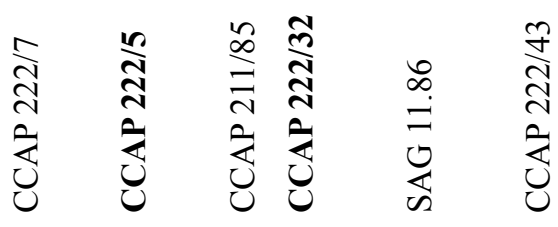

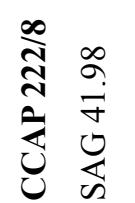




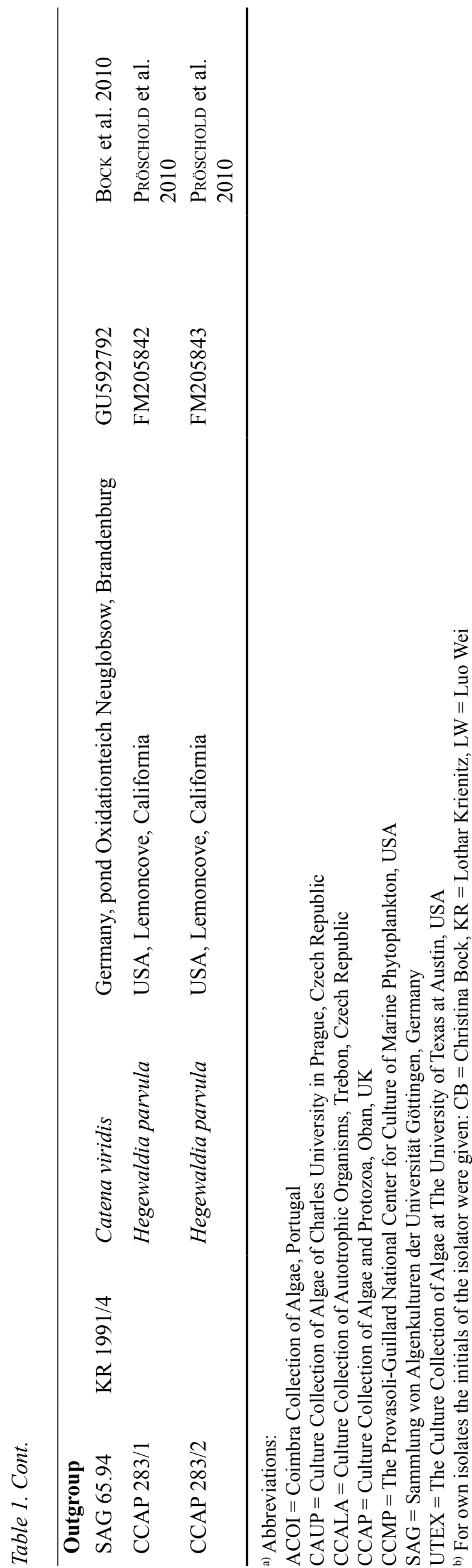

of 1.5. Regions of instability were excluded by computing a $90 \%$ consensus alignment, resulting in 2815 alligned bases. The phylogenetic tree and the corresponding bootstrap values were interfered as described above with the ML models: 18S (GTR:G:5 model, 1807 bases), ITS1 ( J1:G:5 model, 470 bases), 5.8S (HKY model, 139 bases), ITS2 (GTR:G:5 mode, 399 bases).

The ITS2 secondary structure was constructed with the help of mfold with the $D$. ehrenbergianum structure as template (Bock et al. 2011b; Krienitz et al. 2010) to locate nonhomoplasious synapomorphies (NHS), hemi-compensatory base changes (h-CBCs) and compensatory base changes (CBCs) according to Marin et al. (2003) and Coleman (2003, 2007). Structures were drawn by PseudoViewer (BYUN \& HAN 2006).

\section{Results}

Under field conditions (Figs 1-5), colonies with Dictyosphaerium-morphotype covered by mucilaginous envelopes (Fig. 1) were clearly identifiable. The inner anatomy of the cells was identical to Chlorella: the parietal, cup-shaped chloroplast carried a starch-sheathed pyrenoid. Cell shape and size and several features of colony organization showed a certain amount of variability. The cells, which were 3-14 $\mu \mathrm{m}$ in diameter, varied from spherical to ovoid. The interconnecting strands between the cells, established by mother cell wall remnants after liberation of the autospores were simple, cross-shaped (Fig. 2) or more complex (Fig. 3) depending on the number of cells joined together within the colony. The stalks attached the cells at the apical (Fig. 1) or at the longitudinal side (Figs 4 and 5). Under culture conditions (Figs 6 and 7), some strains became solitary but most showed more or less the characteristic colonies of the Dictyosphaerium-morphotype. Generally, the colonial life form disappeared after longer maintenance under the conditions of the strain collection. Colonies were best visible on fresh agar-cultures or occasionally during the first days of freshly inoculated suspension cultures.

In strains belonging to the close relatives of Chlorella, such as the members of the genus Hindakia (Fig. 6), the mucilaginous stalks attached the cells at their apical end. In contrast, cells of the Parachlorella/Dictyosphaerium-relationship 
Table 2. Comparison of CBCs and hemi-CBCs within the ITS2 between the newly erected species.

\begin{tabular}{|c|c|c|c|c|}
\hline & $\begin{array}{l}\text { Helix I } \\
\text { CBC/ hemi- } \\
\text { CBC }\end{array}$ & $\begin{array}{l}\text { Helix II } \\
\text { CBC/ hemi- } \\
\text { CBC }\end{array}$ & $\begin{array}{c}\text { Helix III } \\
\mathrm{CBC} / \text { hemi-CBC }\end{array}$ & $\begin{array}{c}\text { Helix IV } \\
\text { CBC/ hemi-CBC }\end{array}$ \\
\hline $\begin{array}{c}\text { Marasphaerium } \\
\text { gattermannii } \\
\text { vs } \\
\text { Compactochlorella kochii }\end{array}$ & $-1-$ & $5 /-$ & $-/ 2$ & $6 /-$ \\
\hline $\begin{array}{c}\text { Compactochlorella kochii } \\
\text { vs } \\
\text { Compactochlorella } \\
\text { dohrmannii }\end{array}$ & $-1-$ & $2 / 1$ & $1 / 2$ & $1 / 1$ \\
\hline $\begin{array}{c}\text { Compactochlorella } \\
\text { dohrmannii } \\
\text { vs } \\
\text { Masaia oloidia }\end{array}$ & $1 / 1$ & $3 /-$ & $-/ 2$ & $1 / 1$ \\
\hline $\begin{array}{c}\text { Masaia oloidia } \\
\text { vs } \\
\text { Kalenjinia gelatinosa }\end{array}$ & $-1-$ & $2 / 1$ & $1 / 3$ & $3 /-$ \\
\hline
\end{tabular}

were attached by the stalks at their longitudinal end (Fig. 7).

Three of the African strains of Chlorellaceae were solitary and belonged unambiguously to the genus Chlorella. The 24 colony-forming strains of Dictyosphaerium-morphotype from African waters evolved in seven different lineages of Chlorellaceae (Figs 8 and 9). Four strains, from the lakes Victoria and Baringo, belonged to the genus Hindakia within the Chlorellaclade. The other strains occurred in different clusters of the Parachlorella-clade. Whereas the sister-relationship of the Chlorella- and the Parachlorella-clade was supported sufficiently, the general topology of the lineages within these two clades was not supported by our analyses. However, the position of the genus Hegewaldia previously assigned to the Chlorella-clade is unclear (Fig. 9).

Eight African isolates belonged to the genus Dictyosphaerium, seven of them were designated to the type species $D$. ehrenbergianum NÄGELI, and the other species was determined as $D$. libertatis C. Bock, Pröschold et Krienitz. Closely related to these two clusters is the strain CCAP 222/25 from Uganda, which will be studied in more detail by Pavel Škaloud and his team. Two European strains (ACOI 1988 and CCAP 222/1C) were related to a cluster containing the strain CCAP 222/24 from the Mara river in Kenya, which is described as Marasphaerium gattermannii gen. et sp. nov. in this paper. Next to these lineages evolved members of the genera Mucidosphaerium and a cluster containing three African strains described below as Compactochlorella dohrmannii and C. kochii gen. and sp. nov. From C. kochii four strains were analysed, two of them from Africa and two from Germany. Unfortunately, the DNA sequence from the African strain in the culture collection (CCAP 222/7) was imprecise at the end of the ITS2 and therefore we selected the cultured strain CCAP 222/61 from Germany as authentic strain those sequence was complete. Adjacent to these lineages, three strains from Kenya's standing waters, which are newly described here as Masaia oloidia gen. et sp. nov., established its own cluster. The strain CCAP 222/43 exhibited typical colonies of a Dictyosphaerium-morphotype and clustered together with the needle-shaped Closteriopsis acicularis (G.M. SMith) Belcher et Swale. Furthermore, two new spherical and colonial strains from the Nakuru sewage oxidation pond, described here as Kalenjinia gelatinosa gen. et sp. nov., established a lineage placed between Closteriopsis and the colonial needle-shaped Dicloster acuatus JAO, WEI et HU. 


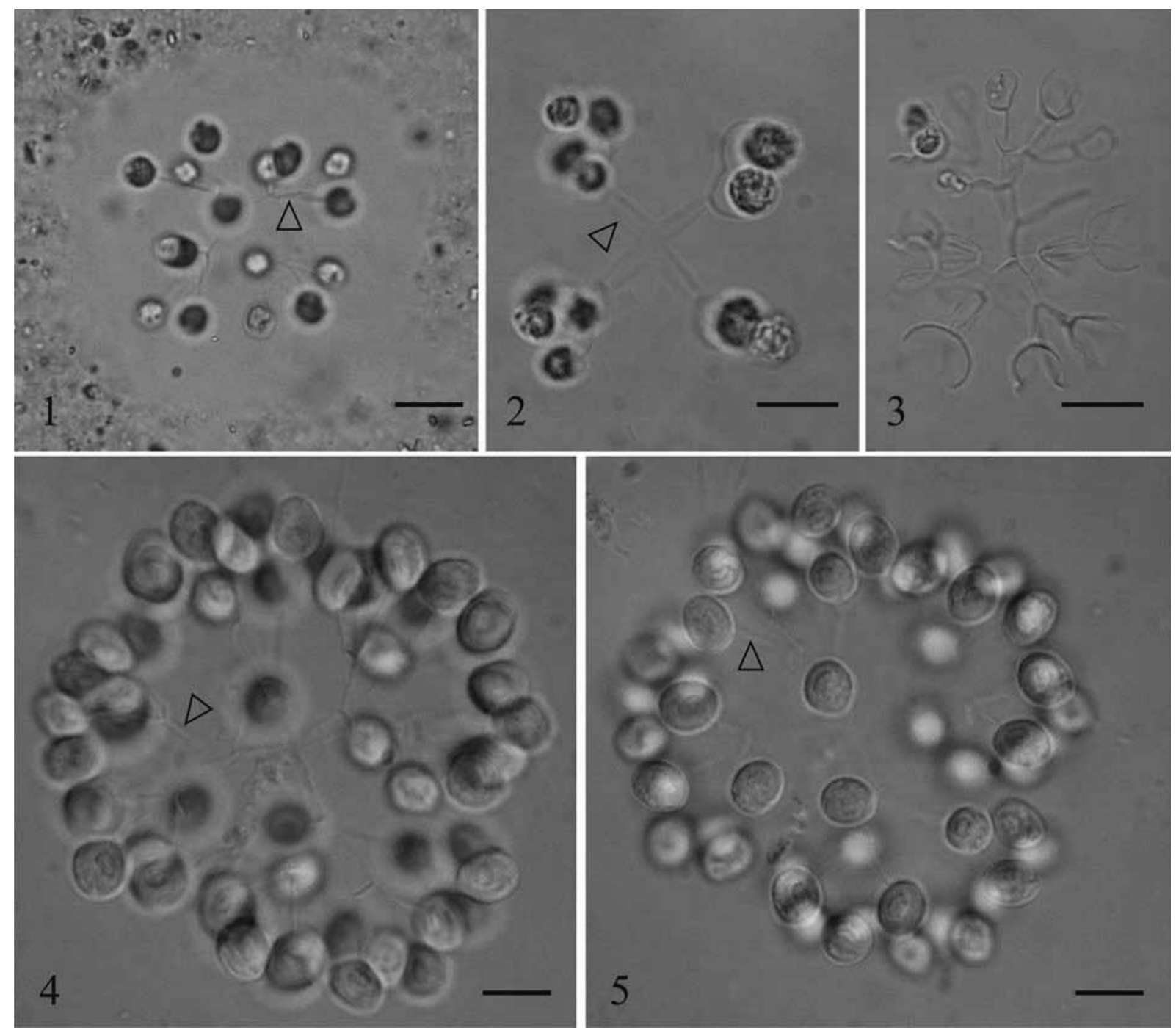

Figs 1 - 5. The Dictyosphaerium-morphotype in field samples from Lake Victoria (Figs 1-3) and a sewage pond at Nakuru (Figs 4, 5). The empty arrowhead indicates the interconnecting strands between the cells. (1) spherical colony covered by a thick mucilaginous envelope which is made visible by silt particles and picoplanktonic cyanobacteria. (2) colony with two-, or four-celled mother cells and cross-shaped interconnecting strands; (3) articulated strands of a colony of mother cells which already liberated the autospores (only two autospores remained in the upper left mother cell). Scale bars $10 \mu \mathrm{m}$.

The topology of the phylogenetic trees recovered from two different alignments (manual alignment, Fig. 8, and alignment computed with ClustelW, Fig. 9) was in general congruent. No major discrepancies occurred between the different alignment methods; differences were only observed in the placements of lineages that received no statistical support in either method. Within the Chlorella-clade, the cluster with sequences of Micractinium and Didymogenes exchanged position with the Hindakia/Heynigia cluster. Within the Parachlorella-clade, the cluster containing Marasphaerium, Mucidosphaerium, Compactochlorella and ACOI 1988/CCAP222/1C (Fig. 8) is separated in different lineages (Fig. 9). Small differences were also observed within the bootstrap values of the lineages.

To evaluate the newly erected five species according to the $\mathrm{CBC}$ concept, we compared the number of $\mathrm{CBCs}$ and hemi-CBCs and found a remarkable number of differences among the taxa (for details see Fig. 10, and Table 2). Marasphaerium gattermannii and Compactochlorella kochii differ in $11 \mathrm{CBCs}$ and 2 hemi-CBCs with additional base pairs in all helices within the ITS2. The two species belonging to the new genus Compactochlorella differ in $4 \mathrm{CBCs}$ and 4 hemi-CBCs and additional base pairs in Helices I, II and IV. Considerable CBCs occurred between the genera Compactochlorella and Masaia (5 CBCs and 4 hemi-CBCs) and between Masaia and Kalenjinia (6 CBCs; 4 hemi-CBCs). 

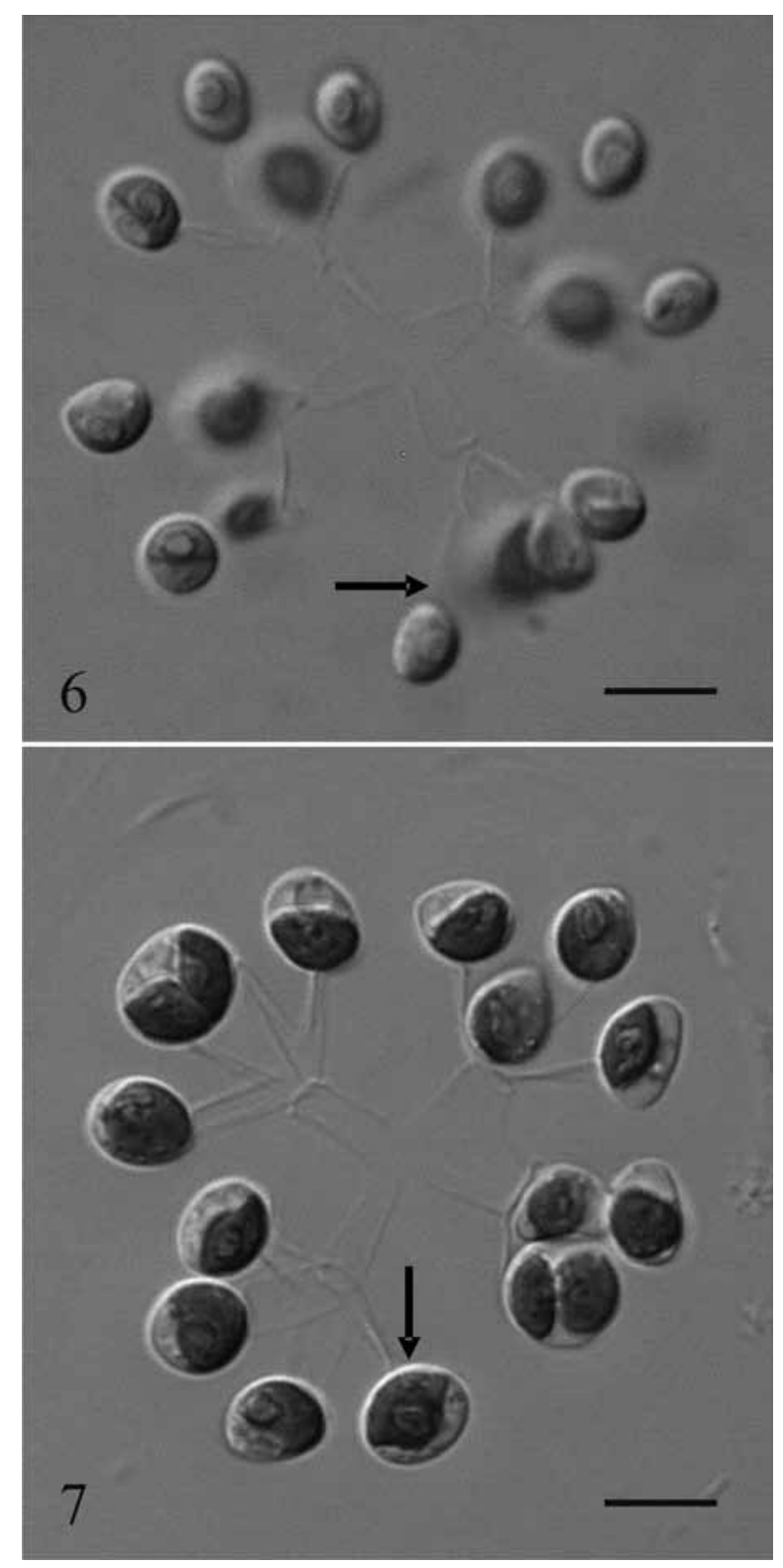

Figs 6, 7. The Dictyosphaerium-morphotype in culture. The black arrows indicate the place of attachment of the interconnecting strands to the cell wall. (6) colony of Hindakia fallax (CCAP 222/29), a member of the Chlorella-clade; the strands are attached to the apical cell side; (7) colony of Dictyosphaerium ehrenbergianum (CCAP 222/27), a member of the Parachlorella-clade; the strands are attached to the longitudinal cell side. Scale bars $10 \mu \mathrm{m}$.

To align the phylogenetic findings with the morphology features, the five authentic strains of the new taxa were subjected again to microscopic investigations. Micrographs of these authentic strains are given in Figs 11-15, whereas drawings including the iconotypes are shown in Figs 16-20. Results of the comparison of their morphological features are provided in Table 3.

\section{Generic and species descriptions}

Marasphaerium Krienitz, C. Bock, KotUt et Pröschold gen. nov.

Latin diagnosis: Cellulae viridis, sphaericae, planctonicae. Chloroplastus unicus, parietalis, poculiformis, pyrenoide granis amylis tecto. Reproductio asexualis autosporum ope, reproductio sexualis ignota. Cellulae solitariae vel in coloniis, 2-4 cellularis, interdum tegumento gelatinoso vestitae. A generibus ceteris familiae ordine nucleotidorum in $18 S$ rDNA et ITS differt.

Cells green, spherical, planktonic. Single cupshaped chloroplast with starch-covered pyrenoid. Asexual reproduction by autosporulation, sexual reproduction not observed. Cells solitary or in colonies of 2-4 cells, covered by a gelatinous envelope. Genus differs from other genera of the family by the order of the nucleotides in SSU and ITS rRNA gene sequences.

Typus generis: Marasphaerium gattermannii Krienitz, C. Bock, Kotut et Pröschold sp. nov.

Etymology: the genus is named according to its locus classicus, the Mara river in the Masai Mara National Reserve, Kenya.

Marasphaerium gattermannii KRIENITZ, C. Bock, Kotut et Pröschold sp. nov.

Latin diagnosis: Cellulae solitariae vel in coloniis, planctonicae, interdum tegumento gelatinoso vestitae. Coloniae parvae, 2-4 cellularis, cellulis funibus subtilibus hyalinis iunctis. Cellulae sphericae, raro late ovalis, 4-13 $\mu \mathrm{m}$ in diametro. Chloroplastus unicus, parietalis, poculiformis, pyrenoide granis amylis tecto. Reproductio asexualis autosporum ope. A speciebus ceteris generis ordine nucleotidorum in $18 \mathrm{~S}$ rDNA et ITS differt.

Cells solitary or in colonies, planktonic, covered by a gelatinous envelope. Colonies small, 2-4 celled, cells connected by hyaline mother cell wall remnants. Cells spherical, seldom broad oval, $4-13 \mu \mathrm{m}$ in diameter. Single cup-shaped chloroplast with starch-covered pyrenoid. Asexual reproduction by autosporulation. Differs from species of other genera by the order of the nucleotides in SSU and ITS rRNA gene sequences.

Holotype: material of the authentic strain CCAP 222/24 is cryopreserved in metabolic inactive state at the Culture Collection of Algae and Protozoa, Oban, Scotland.

Isotype: an air-dried as well as a formaldehydefixed sample of the authentic strain CCAP 222/24, deposited at the Botanical Museum at Berlin- 
Dahlem under the designation B400040739.

Type locality: Mara river in the Masai Mara National Reserve, Kenya.

Etymology: The species is named in memory of the late Rolf Gattermann, who was a leading authority in Zoology and behavioural biology of mammals. He was impressed by the wildlife in East Africa and inspired the first author to study African nature.

Authentic strain: CCAP 222/24.

Iconotype: Figure 16*

\section{Compactochlorella Krienitz, C. Воск, KotUt et Pröschold gen. nov.}

Latin diagnosis: Cellulae viridis, sphaericae, planctonicae. Chloroplastus unicus, parietalis, poculiformis, pyrenoide granis amylis tecto. Reproductio asexualis autosporum ope, reproductio sexualis ignota. Cellulae solitariae vel in coloniis, 2-4 cellularis, vel in aggregationibus compactis, interdum tegumento gelatinoso vestitae. A generibus ceteris familiae ordine nucleotidorum in $18 S$ rDNA et ITS differt.

Cells green, spherical, planktonic. Single cupshaped chloroplast with starch-covered pyrenoid. Asexual reproduction by autosporulation, sexual reproduction not observed. Cells solitary or in colonies of 2-4 cells, or in compact aggregations, covered by a gelatinous envelope. Genus differs from other genera of the family by the order of the nucleotides in SSU and ITS rRNA gene sequences.

Typus generis: Compactochlorella kochii Krienitz, C. Bock, Kotut et Pröschold sp. nov.

Etymology: The genus is named according to the compact aggregations which were often developed by the colonies of the type species.

\section{Compactochlorella kochii KRIENITZ, C. Bock,} Kotut et Pröschold sp. nov.

Latin diagnosis: Cellulae solitariae vel in coloniis, 2-4 cellularis, vel in aggregationibus compactis, interdum tegumento gelatinoso vestitae, planctonicae. Cellulis funibus subtilis hyalinis iunctis. Cellulae ovoides, ovalis vel sphericae, $3-12 \times 2.5-12 \mu \mathrm{m}$. Chloroplastus unicus, parietalis, poculiformis, pyrenoide granis amylis tecto. Reproduction asexualis autosporum ope. A speciebus ceteris generis ordine nucleotidorum in $18 S$ rDNA et ITS differt.

Cells solitary or in 2-4 celled colonies, or in compact aggregations, covered by a gelatinous envelope, planktonic. Cells connected by hyaline stalks. Cells ovoid, oval or spherical, 3-12 $\times$

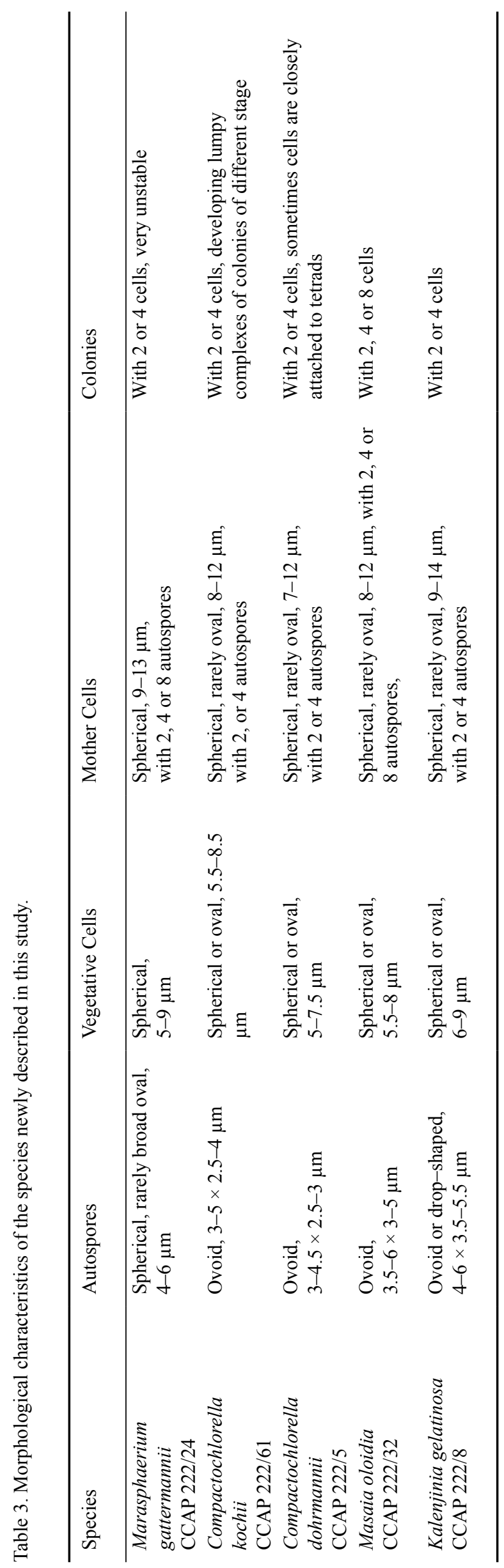




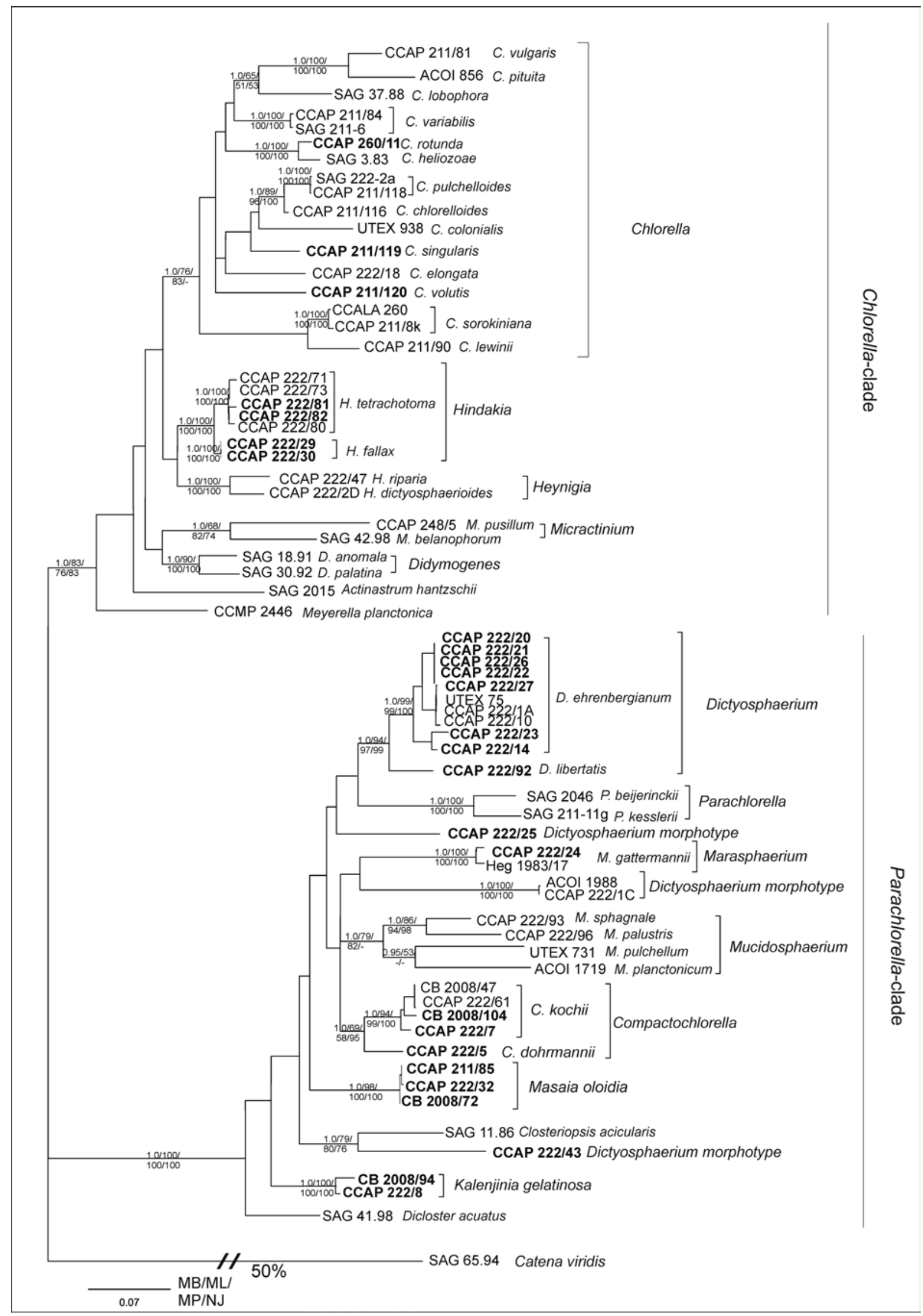

Fig. 8. Maximum likelihood phylogram of the Chlorellaceae with Catena viridis as outgroup inferred from a concatenated set of SSU and ITS sequences. The phylogram is based on a partitioned dataset with manually aligned sequences according to their secondary structure. Hyphens correspond to values below 50 for BP and below 0.95 for PP. African strains in bold. Scale bar indicates substitutions per site. 


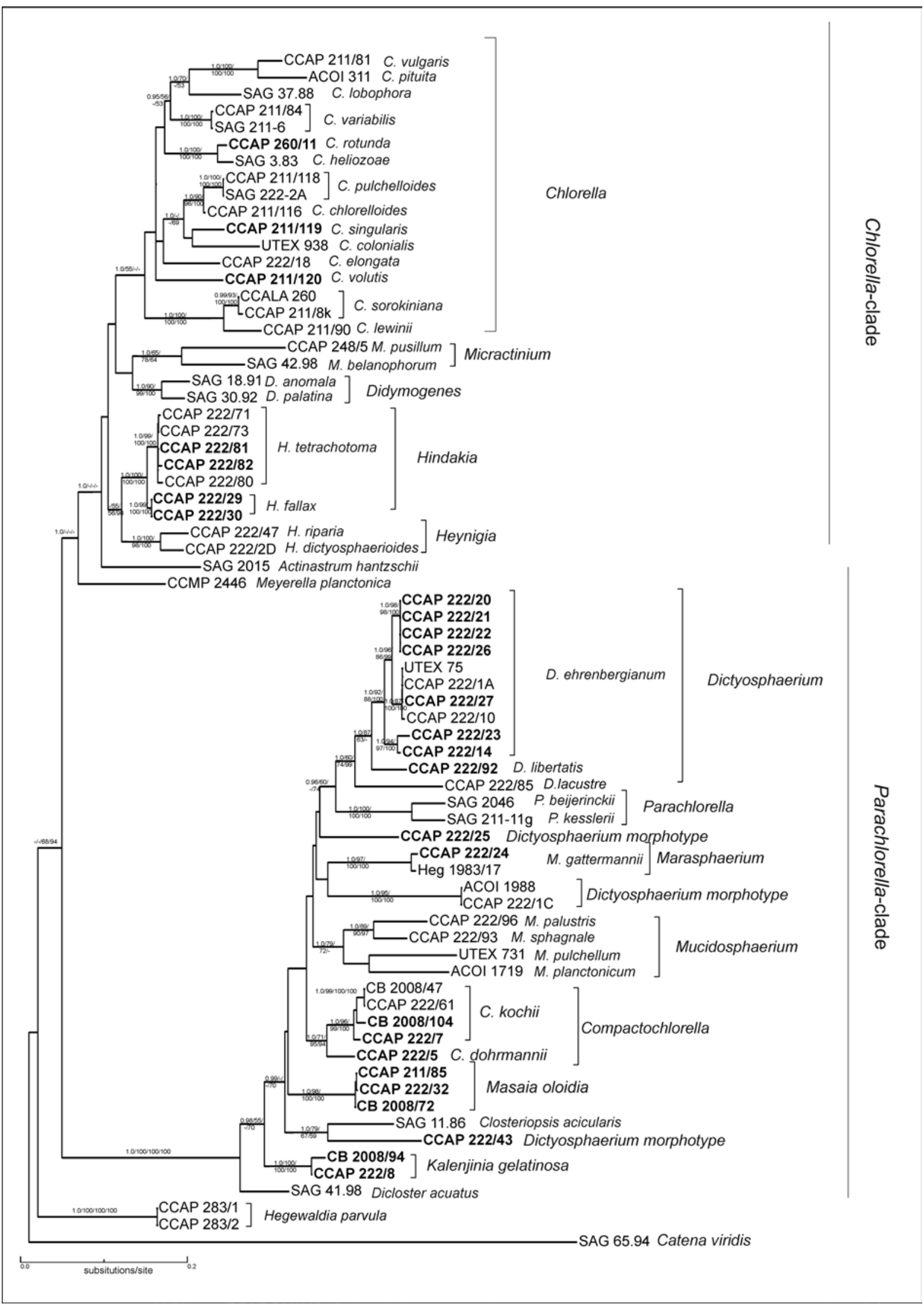

Fig. 9. Maximum likelihood phylogram of the Chlorellaceae with Catena viridis as outgroup inferred from a concatenated set of SSU and ITS sequences. The phylogram is based on a partitioned dataset of a $90 \%$ consensus alignment predicted by SOAP (LOYTYNOJA \& MiLINKOVITCH 2001) under different gap/extension penalties. Hyphens correspond to values below 50 for BP and below 0.95 for PP. African strains in bold. Scale bar indicates substitutions per site. 
2.5-12 $\mu \mathrm{m}$. Single cup-shaped chloroplast with starch-covered pyrenoid. Asexual reproduction by autosporulation. Differs from other species of the genus by the order of the nucleotides in SSU and ITS rRNA gene sequences.

Holotype: material of the authentic strain CCAP 222/61 is cryopreserved in metabolic inactive state at the Culture Collection of Algae and Protozoa, Oban, Scotland.

Isotype: an air-dried as well as a formaldehydefixed sample of the authentic strain CCAP 222/61, deposited at the Botanical Museum at BerlinDahlem under the designation B40004040.

Type locality: lake Jabeler See, MecklenburgWestern Pomerania, Germany.

Etymology: the species is named in honour of Frank Koch, an authority in entomology. He makes frequent work visits to Africa, and inspired the first author to study African nature.

Authentic strain: CCAP 222/61.

Iconotype: Figure $17^{*}$

Compactochlorella dohrmannii KRIENITZ, C. Bock, Kotut et Pröschold sp. nov.

Latin diagnosis: Cellulae planctonicae, solitariae vel in coloniis, 2-4 cellularis, interdum tegumento gelatinoso vestitae. Cellulis funibus subtilis hyalinis iunctis. Cellulae ovoides, ovalis vel sphericae, 3-12 × 2.5-10 um. Chloroplastus unicus, parietalis, poculiformis, pyrenoide granis amylis tecto. Reproductio asexualis autosporum ope. A speciebus ceteris generis ordine nucleotidorum in $18 S$ rDNA et ITS differt.

Cells solitary or in $2-4$ celled colonies, or in compact aggregations, covered by a gelatinous envelope, planktonic. Cells connected by hyaline stalks. Cells ovoid, oval or spherical, 3-12 $\times$ 2.5-10 $\mu \mathrm{m}$. Single cup-shaped chloroplast with starch-covered pyrenoid. Asexual reproduction by autosporulation. Differs from other species of the genus by the order of the nucleotides in SSU and ITS rRNA gene sequences.

Holotype: material of the authentic strain CCAP $222 / 5$ is cryopreserved in metabolic inactive state at the Culture Collection of Algae and Protozoa, Oban, Scotland.

Isotype: an air-dried as well as a formaldehydefixed sample of the authentic strain CCAP 222/5, deposited at the Botanical Museum at BerlinDahlem under the designation B40004041.

Type locality: sewage oxidation pond, Nakuru, Kenya.

Etymology: the species is named in honour of Klaus Dohrmann, a microbiologist. He inspired the first author to study microphytes.

Authentic strain: CCAP 222/5.

Iconotype: Figure 18*

\section{Masaia Krienitz, C. Bock, Kotut et Pröschold gen. nov.}

Latin diagnosis: Cellulae viridis, sphaericae, planctonicae. Chloroplastus unicus, parietalis, poculiformis, pyrenoide granis amylis tecto. Reproductio asexualis autosporum ope, reproductio sexualis ignota. Cellulae solitariae vel in coloniis, 2-4-8 cellularis, interdum tegumento gelatinoso vestitae. A generibus ceteris familiae ordine nucleotidorum in $18 \mathrm{~S}$ rDNA et ITS differt.

Cells green, spherical, planktonic. Single cupshaped chloroplast with starch-covered pyrenoid. Asexual reproduction by autosporulation, sexual reproduction not observed. Cells solitary or in colonies of 2-4-8 cells, covered by a gelatinous envelope. Genus differs from other genera of the family by the order of the nucleotides in SSU and ITS rRNA gene sequences.

Typus generis: Masaia oloidia Krienitz, C. Bock, Kotut et Pröschold sp. nov.

Etymology: the genus is named after the Masai, a famous tribe living in East Africa

\section{Masaia oloidia Krienitz, C. Bock, Kotut et Pröschold sp. nov. \\ Latin diagnosis: Cellulae solitariae vel in coloniis, 2-4-8 cellularis, interdum tegumento gelatinoso vestitae, planctonicae. Cellulis funibus subtilis hyalinis iunctis. Cellulae ovoides, ovalis vel sphericae,

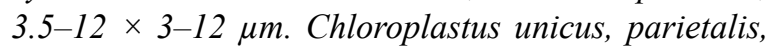 poculiformis, pyrenoide granis amylis tecto. Reproductio asexualis autosporum ope. A speciebus ceteris generis ordine nucleotidorum in $18 \mathrm{~S}$ rDNA et ITS differt.}

Cells solitary or in $2-4-8$ celled colonies, covered by a gelatinous envelope, planktonic. Cells connected by hyaline stalks. Cells ovoid, oval or spherical, $3.5-12 \times 3-12 \mu \mathrm{m}$. Single cupshaped chloroplast with starch-covered pyrenoid. Asexual reproduction by autosporulation. Differs from species of other genera by the order of the nucleotides in SSU and ITS rRNA gene sequences.

Holotype: material of the authentic strain CCAP $222 / 32$ is cryopreserved in metabolic inactive state at the Culture Collection of Algae and Protozoa, Oban, Scotland.

Isotype: an air-dried as well as a formaldehyde- 


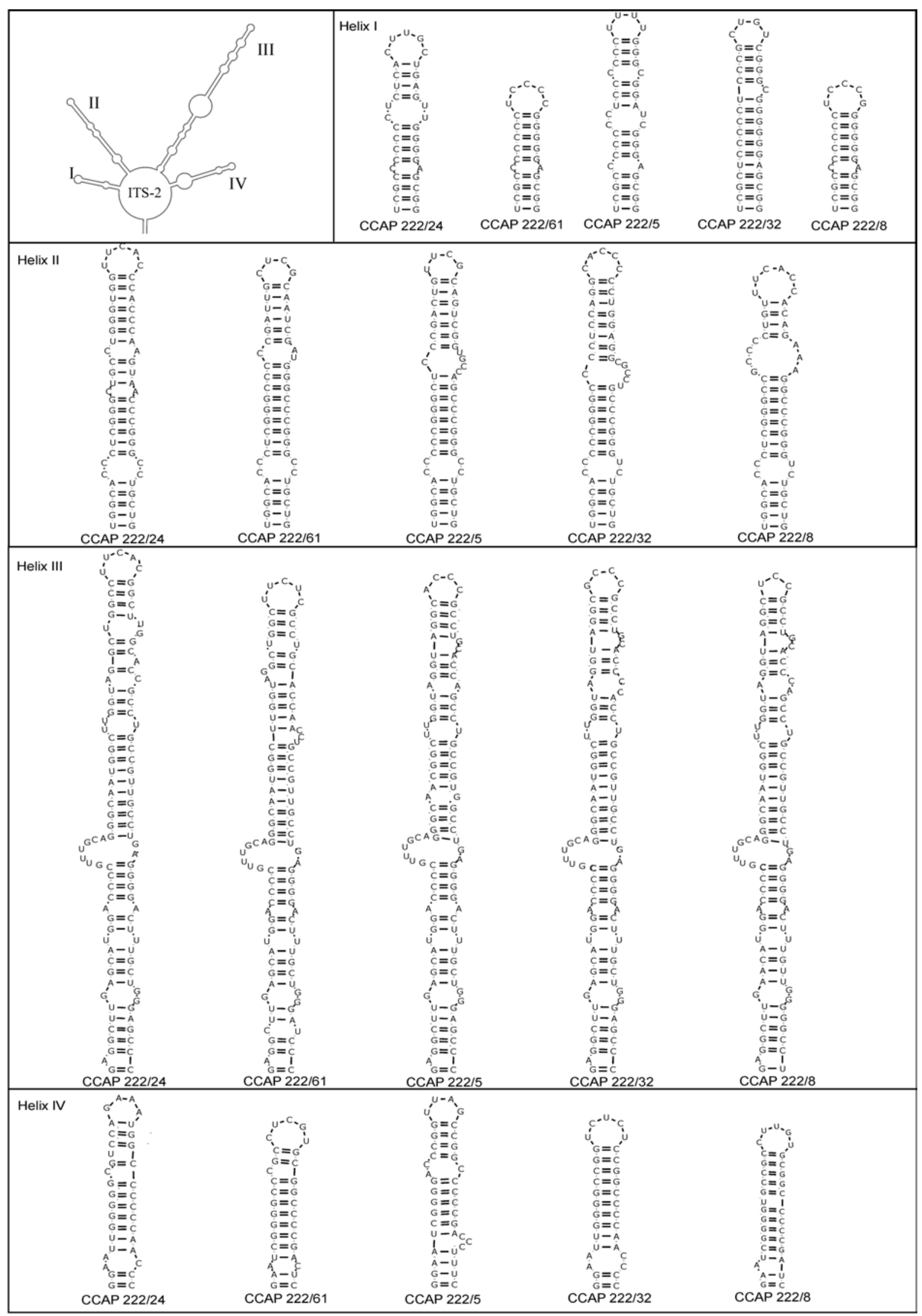

Fig. 10. Comparison of the secondary structure of the helices I - IV of ITS2 rRNA gene of authentic strains of Marasphaerium gattermannii (CCAP 222/24), Compactochlorella kochii (CCAP 222/61), Compactochlorella dohrmannii (CCAP 222/5), Masaia oloidia (CCAP 222/32) and Kalenjinia gelatinosa (CCAP 222/8). The number of differences is given in Table 2. 

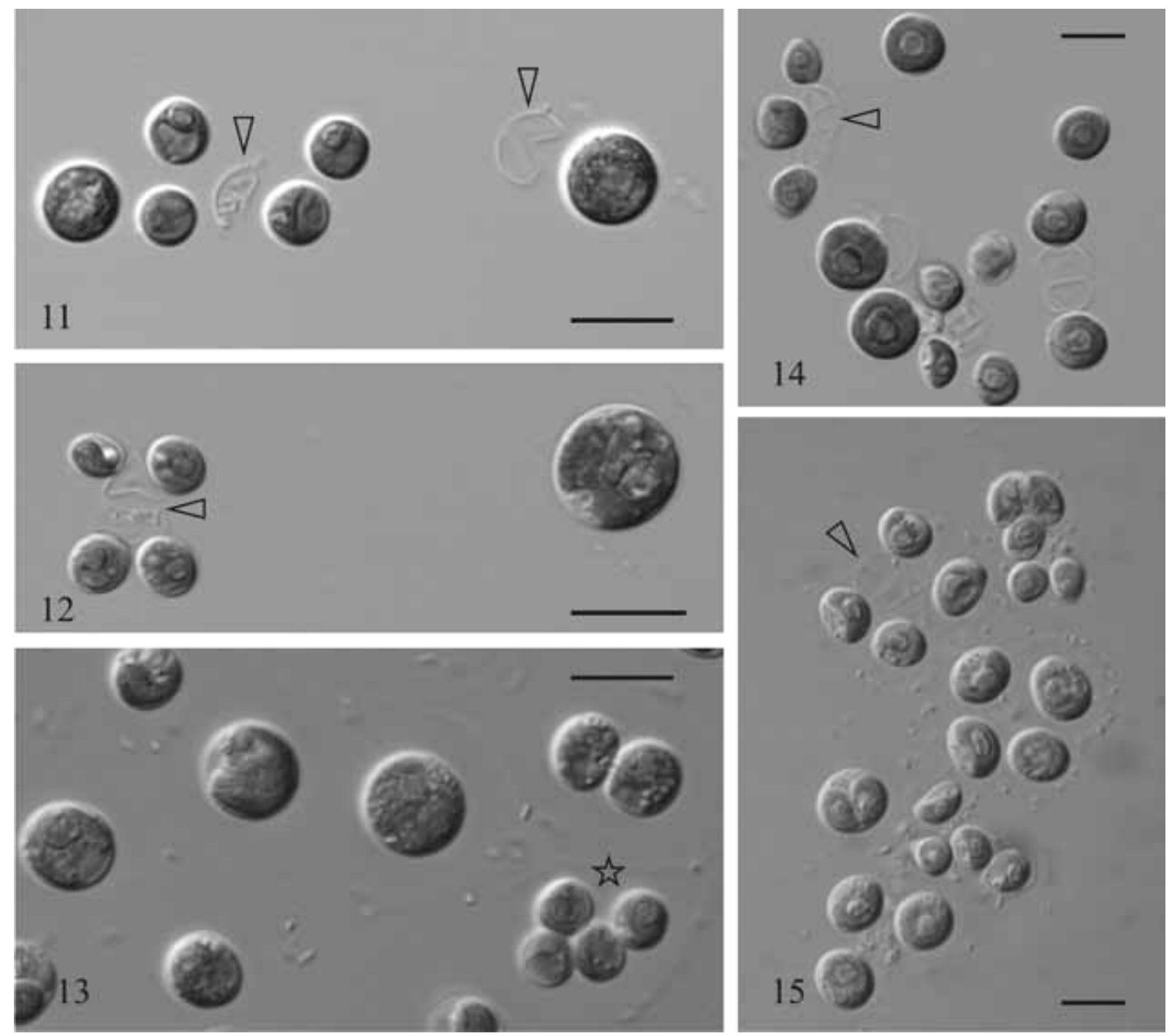

Figs 11 - 15. Microphotographs of the newly described genera and species: (11) Marasphaerium gattermannii; (12) Compactochlorella kochii; (13) Compactochlorella dohrmannii; (14) Masaia oloidia; (15) Kalenjinia gelatinosa. Scale bars $10 \mu \mathrm{m}$.

fixed sample of the authentic strain CCAP 222/32, deposited at the Botanical Museum at BerlinDahlem under the designation B40004042.

Type locality: Lake Oloidien, Kenya.

Etymology: the species is named after its the locus classicus, lake Oloidien in Kenya.

Authentic strain: CCAP 222/32.

Iconotype: Figure 19*

\section{Kalenjinia Krienitz, C. Bock, KotUt et Pröschold gen. nov.}

Latin diagnosis: Cellulae viridis, sphaericae, planctonicae. Chloroplastus unicus, parietalis, poculiformis, pyrenoide granis amylis tecto. Reproductio asexualis autosporum ope, reproductio sexualis ignota. Cellulae solitariae vel in coloniis, 2-4 cellularis, interdum tegumento gelatinoso vestitae. A generibus ceteris familiae ordine nucleotidorum in $18 \mathrm{~S}$
rDNA et ITS differt.

Cells green, spherical, planktonic. Single cupshaped chloroplast with starch-covered pyrenoid. Asexual reproduction by autosporulation, sexual reproduction not observed. Cells solitary or in colonies of 2-4 cells, covered by a gelatinous envelope. Genus differs from other genera of the family by the order of the nucleotides in SSU and ITS rRNA gene sequences.

Typus generis: Kalenjinia gelatinosa KRIENITZ, C. Bock, Kotut et Pröschold sp. nov.

Etymology: the genus is named after the Kalenjin, a famous tribe of long distance runners in Kenya.

Kalenjinia gelatinosa Krienitz, C. Bock, KotUt et Pröschold sp. nov. 


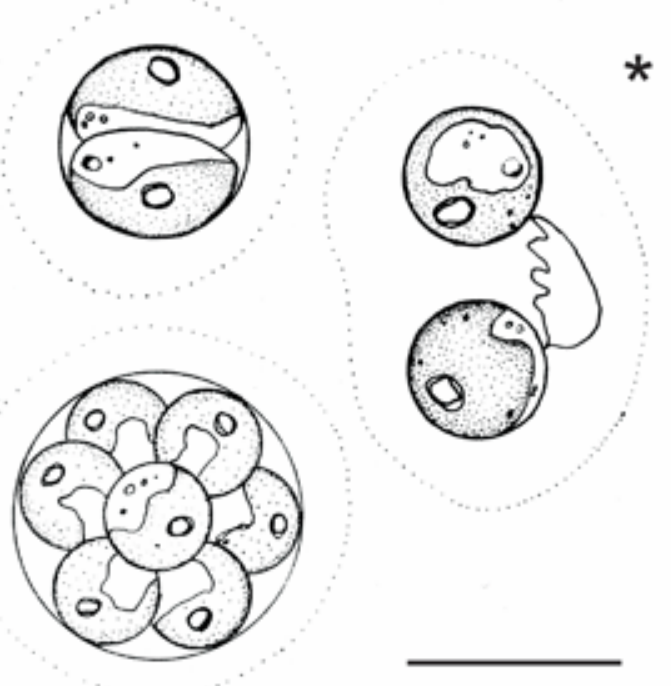

16

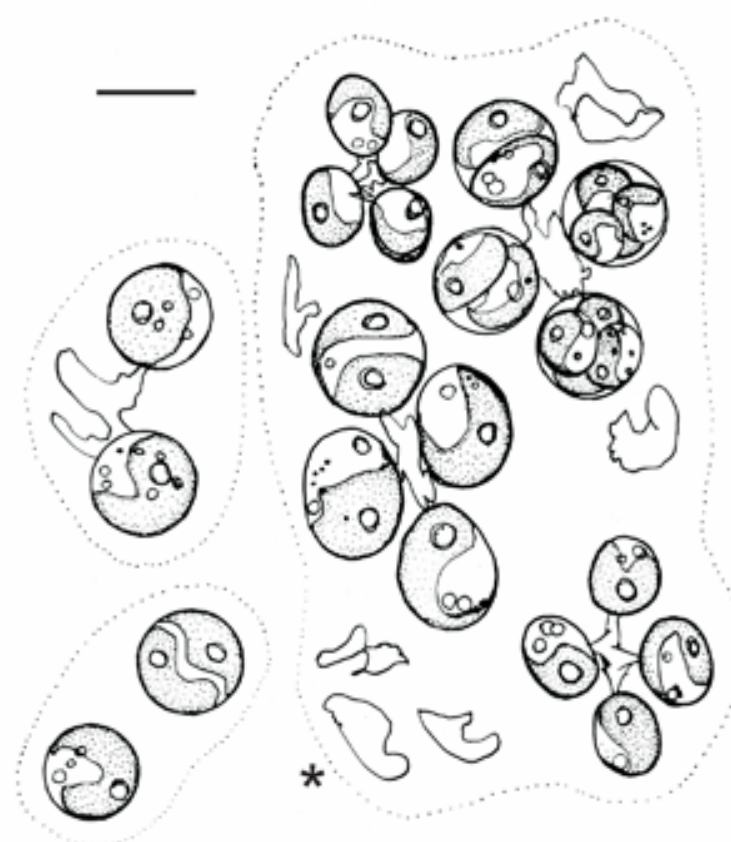

17

Fig 16. Drawings of light microscopy characters of Marasphaerium gattermannii in culture. The iconotype is indicated by an asterisk. Scale bar $10 \mu \mathrm{m}$.

Fig 17. Drawings of light microscopy characters of Compactochlorella kochii in culture. The iconotype is indicated by an asterisk. Scale bar $10 \mu \mathrm{m}$.

Latin diagnosis: Cellulae solitariae vel in coloniis, 2-4 cellularis, interdum tegumento gelatinoso vestitae, planctonicae. Cellulis funibus subtilis hyalinis iunctis. Cellulae ovoides, guttae-formis, ovalis vel sphericae, 4-14 × 3.5-9 $\mu \mathrm{m}$. Chloroplastus unicus, parietalis, poculiformis, pyrenoide granis amylis tecto. Reproductio asexualis autosporum ope. A speciebus ceteris generis ordine nucleotidorum in $18 S \mathrm{rDNA}$ et ITS differt.
Cells solitary or in $2-4$ celled colonies, covered by a gelatinous envelope, planktonic. Cells connected by hyaline stalks. Cells ovoid, drop-shaped, oval or spherical, 4-14 × 3.5-9 $\mu \mathrm{m}$. Single cupshaped chloroplast with starch-covered pyrenoid. Asexual reproduction by autosporulation. Differs from species of other genera by the order of the nucleotides in SSU and ITS rRNA gene sequences.

Holotype: material of the authentic strain CCAP $222 / 8$ is cryopreserved in metabolic inactive state at the Culture Collection of Algae and Protozoa, Oban, Scotland.

Isotype: an air-dried as well as a formaldehydefixed sample of the authentic strain CCAP 222/8, deposited at the Botanical Museum at BerlinDahlem under the designation B40004043.

Type locality: sewage oxidation pond, Nakuru, Kenya.

Etymology: the species is named according to the gelatinous envelope which covers the alga.

Authentic strain: CCAP 222/8.

Iconotype: Figure $20^{*}$.

\section{Discussion}

How diverse are coccoid green algae of the Dictyosphaerium-morphotype from African inland waters based on morphology and phylogeny?

According to KrIENITZ et al. (2004), the attachment of mucilaginous strands on either the apical or longitudinal side of the cells serves as a morphological criterion that can be used to roughly differentiate between members of the Chlorellaand Parachlorella-clades respectively. However, very limited phenotypic criteria were given to differentiate between species and genera (see Table 3). In contrast, the results revealed a high genotypic diversity of the Dictyosphaerium-like algae. This morphotype of spherical colonial green algae evolved independently within seven different evolutionary lineages of Trebouxiophyceae. Within the Chlorella-clade, two species of colony-forming Hindakia, H. tetrachotoma and $H$. fallax, were established as new combinations by Bock et al. (2010). Additionally, three solitary African strains were placed directly in the genus Chlorella and given new descriptions as Chlorella rotunda, C. singularis and C. volutis $\mathrm{C}$. Bock, KrienitZ et Pröschold (BOCK et al. 2011a). After 


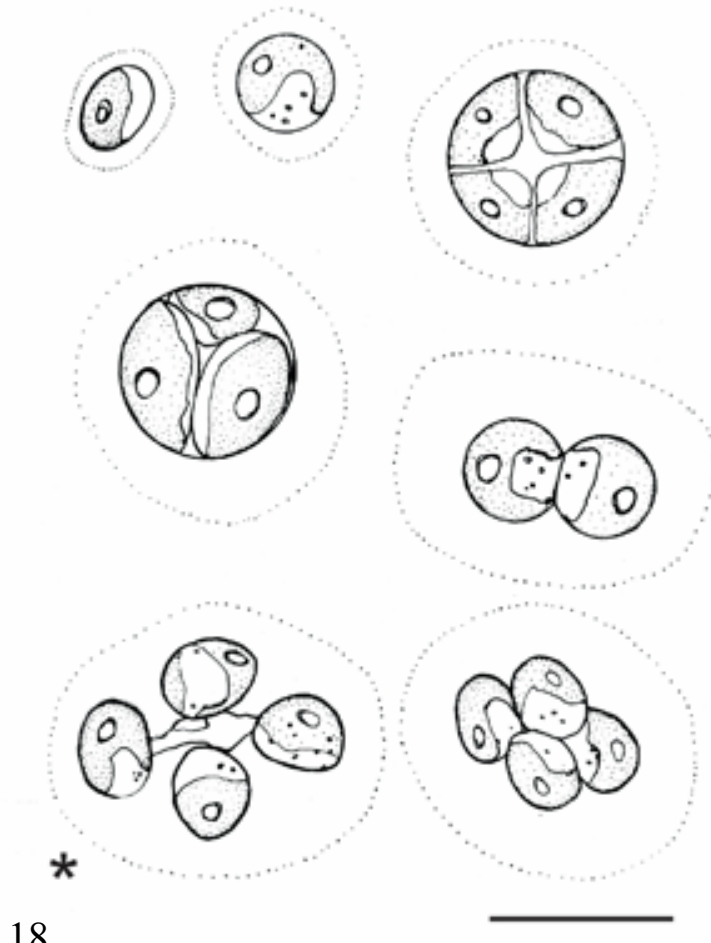

18

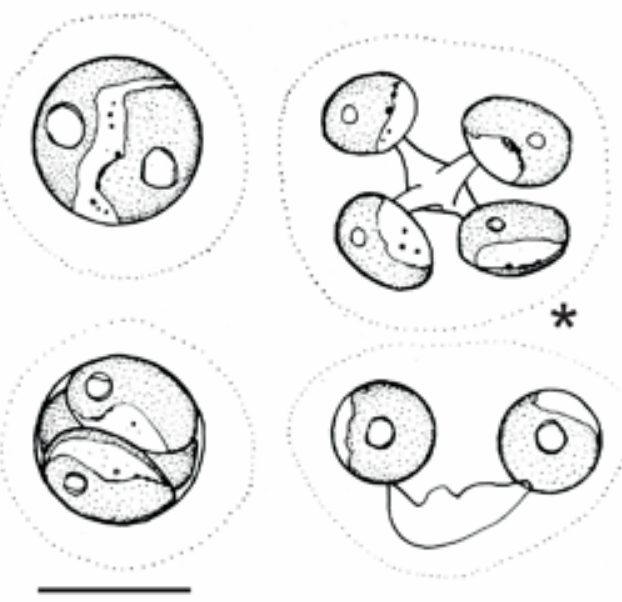

19

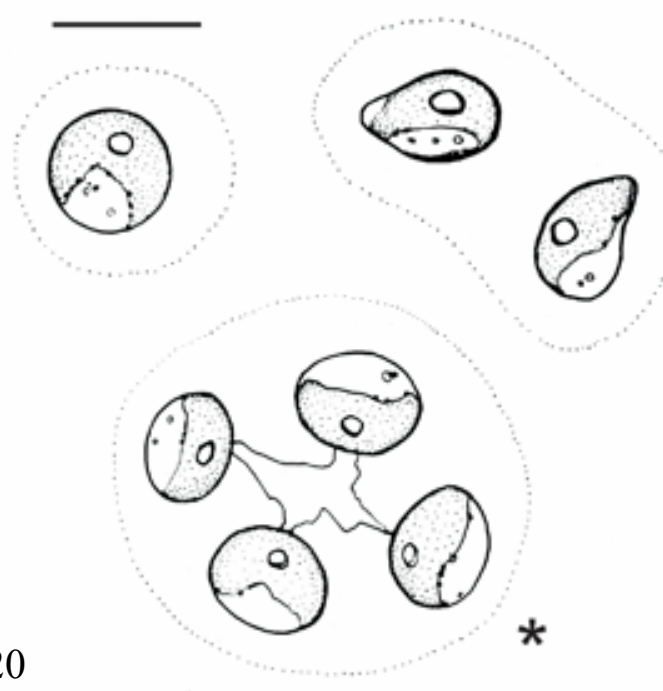

the description of colony-forming members of Chlorella by Bock et al. (2011a) such as $C$. colonialis C. Bock, KrIENITz et Pröschold, we expected similar species to occur also in our samples. However, we did not find such species in our study.

Based on the careful inventory provided by Huss et al. (1999), at present, we have to realize step by step that the diversity of the Chlorellaceae is much higher than expected by the authors cited. Already MüllER et al. (2005) revealed by amplified fragment length polymorphism (AFLP) analyses of strains of Chlorella vulgaris BEIJERINCK from different international strain collections a considerable genomic divergence supporting the existence of cryptic species.

In the Parachlorella-clade, six lineages had the Dictyosphaerium-morphotypes. The fact that a huge genetic diversity is hidden by a relatively uniform shape is widely reported in Trebouxiophyceae, for example, in ellipsoidal Chlorella-like algae (DARIENKO et al. 2010) and spherical Chlorella-like algae (Bock et al. 2011a, PröschOLd et al. 2011a). This high genetic diversity resulted in the description of five new species placed in four new genera in this study (see Generic and species descriptions). Furthermore, two lineages contained Dictyosphaerium-morphospecies, which were not considered in detail in this study. The strain CCAP 222/25 evolved next to the lineages of Dictyosphaerium and Parachlorella and will be studied and described by Škaloud and co--workers in near future. The strain CCAP 222/43, which is closely related to the needle-shaped Closteriopsis acicularis exhibited typical Dictyosphaerium-like colonies. We did not describe this strain as a new taxon, because this enigmatic relationship of so different morphotypes needs further investigations including a wider collection of strains.

Ourresults revealed that the highest diversity of Chlorellaceae occurred in Nakuru town sewage

\footnotetext{
$\overleftarrow{\text { Fig 18. Drawings of light microscopy characters of }}$ Compactochlorella dohrmannii in culture. The iconotype is indicated by an asterisk. Scale bar $10 \mu \mathrm{m}$.
}

Fig 19. Drawings of light microscopy characters of Masaia oloidia in culture. The iconotype is indicated by an asterisk. Scale bar $10 \mu \mathrm{m}$.

Fig 20. Drawings of light microscopy characters of Kalenjinia gelatinosa in culture. The iconotype is indicated by an asterisk. Scale bar $10 \mu \mathrm{m}$. 
pond, where we found Chlorella singularis, Compactochlorella dohrmannii, Masaia oloidea and Kalenjinia gelatinosa. Obviously, such sewage ponds are hot spots for occurrence of the close relatives of Chlorella (UHLMANN 1966, 1967). Котит et al. (2010) also detected by light microscopy Hindakia tetrachotoma (syn. Dictyosphaerium tetrachotomum PRINTz). In our survey, we were not successful in the isolation of Hindakia from Nakuru sewage pond. However, we collected it from Lake Baringo.

The high diversity of the Dictyosphaeriummorphotype is also shown outside the Trebouxiophyceae. Within the Chlorophyceae a clade evolved a cluster containing solitary and colonial species of the genus Mychonastes (Krienitz et al. 2011). Previously, the colonial Dictyosphaerium-like species were considered as members of the genus Pseudodictyosphaerium (HINDÁK 1988, KRIENITZ et al. 1999). In African inland waters five different Mychonastes-species were found, four of them established colonies: M. afer, M. ovahimbae, M. racemosus and $M$. timauensis KrienItZ, C. Bock, DADHEeCH et PröSchold (KRIENITZ et al. 2011).

\section{Are the tropical Dictyosphaerium-like algae genotypically identical with those from the temperate climatic region?}

We did not find a simple answer to this question. On one hand, strains from both the temperate region and the tropics were found in one clade. For example, the strains of the type species D. ehrenbergianum from UK and Germany (temperate) were similar to those from Kenya and Tunisia (tropics). This was also the case for the filing strains of the members of the genus Hindakia and Compactochlorella from Africa and Europe. In contrast to the above, the clusters of Mucidosphaerium comprised exclusively of strains from Europe while those of Masaia contained only East African strains. These findings are in close agreement with findings of earlier studies on the geographic distribution of algae. Using a morphological approach, KOMÁREK (1983) compared the coccoid green algae from Cuba with species commonly found in the temperate zones. His study revealed that out of total of 109 taxa from this tropical island, 53 taxa were identical to species from the temperate latitudes. The remaining taxa were found exclusively in the tropics, with 21 taxa known only from Cuba. A study on diatoms by HiLLEBRANDT et al. (2001) revealed a decreasing similarity of species composition with increasing geographic distance. COLEMAN (2001) found local adaptation and endemism in phytoflagellates of the genera Pandorina and Volvulina. A study using phenotypic and genotypic criteria (V ANORMELINGEN et al. 2008) established a distribution range for diatoms ranging from a global to a narrow endemic distribution range. Molecular analyses of a marine, picoplanktonic morphospeciescomplex Micromonas pusilla BUTCHER revealed genotypes of global oceanic distribution and genotypes with a more restricted distribution (SLAPETA et al. 2006). All these findings contradict the conception of universal distribution of microorganisms accentuated by FenCHEL et al. (1997), Finley (2002) and Fenchel \& FinLey (2004). Recently, more and more arguments questioning the validity of the universal distribution of microorganisms have been generated (COLEMAN 2002; LOGARES 2006; FOISSNER 2008).

Evidently, phycogeographical considerations and designation of phyco-floral regions are of great interest. PADISÁK (2009) explained that different geographic distribution pattern of algal taxa are as a result of a difference in the balance between the speed of dispersal and the evolution rate: If the dispersal rate is faster than the evolution rate, the taxon has a wide or 'subcosmopolitan' distribution (species occurring throughout the world but only in appropriate habitats). In contrast, if the rate of dispersal is slower than the rate of evolution, floristic regionality is supported. In a study focusing on desmids, a morphologically well studied algal group, Coesel (1996) established the following distinct phycogeographic regions: Indo-Malaysia/Northern Australia, Equatorial Africa, Tropical South and Central America, North America, Extratropical South America, Eastern Asia, Southern Australia and New Zealand, South Africa, Temperate Eurasia and finally the circumpolar and high mountain regions. Further studies should reveal the extent to which these phycogeographic regions apply to the coccoid green algae and other algal groups with a high level of ubiquity.

\section{Acknowledgements}

We thank the Government of Kenya for permission to carry out this research (permit number MOEST 13/001/31 C 90). We are grateful to the German Federal Ministry of Education and Research for its financial support (grant number 01LC0001). Additional financial support was provided by the 
Deutsche Forschungsgemeinschaft (project number KR 1262/11-1+2) and NERC Oceans 2025 and NERC MGF 154 sequencing grant. Three species are dedicated to the colleagues and friends of LK, Klaus Dohrmann, Rolf Gattermann $(\dagger)$, and Frank Koch, who established strong and inspiring teams in all situations. We are indebted to Wei Luo for providing three of the algal strains investigated. Our gratitude is also due to Monika Papke and Reingard Rossberg, for their technical assistance.

\section{References}

BAAs BECKING, L.G.M. (1934): Geobiologie of inleiding tot de milieukunde Diligentia Wetenschappen, Ser. 18/19. - Van Stockum's Gravenhange, 263 pp.

Bock, C., Pröschold, T. \& Krienitz, L. (2010): Two new Dictyosphaerium-morphotype lineages of the Chlorellaceae (Trebouxiophyceae): Heynigia gen. nov. and Hindakia gen. nov. Europ. J. Phycol. 45: 267-277.

Bock, C., Krienitz, L. \& Pröschold, T. (2011a): Taxonomic reassessment of the genus Chlorella (Trebouxiophyceae) using molecular signatures (barcodes), including description of seven new species. - Fottea 11: 293-312.

Bock, C., Pröschold, T. \& Krienitz, L. (2011b): Updating the genus Dictyosphaerium and description of Mucidosphaerium gen. nov. (Trebouxiophyceae) based on morphological and molecular data. - J. Phycol. 47: 638-652.

Byun, Y. \& Han, K. (2006): PseudoViewer: web application and web service for visualizing RNA pseudoknots and secondary structures. Nucl. Acids Res. 34: W416-W422.

Cocquyt, C., Vyverman, W. \& Compère, P. (1993): A checklist of the algal flora of the East African Great Lakes. - Script. Bot. Belg. 8: 1-55.

Coesel, P.F.M. (1996): Biogeography of desmids. Hydrobiologia 336: 41-53.

Coesel, P.F.M. \& Krienitz, L. (2008): Diversity and geographic distribution of desmids and other coccoid green algae. - Biodiv. Conserv. 17: $381-392$.

Coleman, A.W. (2001): Biogeography and speciation in the Pandorina/Volvulina (Chlorophyta) superclade. - J. Phycol. 37: 836-851.

Coleman, A.W. (2002): Microbial eukaryote species. Science 297: 337.

Coleman, A.W. (2003): ITS2 is a double-edged tool for eukaryote evolutionary comparisons. Trends Genet. 19: 370-375.

Coleman, A. W. (2007): Pan-eukaryote ITS2 homologies revealed by RNA secondary structure. - Nucl. Acids Res. 35: 33223329.
Darienko, T., Gustavs, L., Mudimu, O., Rad Menendez, C., Schumann, R., Karsten, U., Friedl. T. \& PRÖschold, T. (2010): Chloroidium, a common terrestrial coccoid green alga previously assigned to Chlorella (Trebouxiophyceae, Chlorophyta). - Eur. J. Phycol. 45: 79-95.

De Wit, R. \& Bouvier, T. (2006): 'Everything is everywhere, but, the environment selects'; what did Baas Becking and Beijerinck really say? Environ. Microbiol. 8: 755-758.

Fawley, M.W., Dean, M.L., Dimmer, S.K. \& Fawley, K.P. (2005): Evaluating the morphospecies concept in the Selenastraceae (Chlorophyceae, Chlorophyta). - J. Phycol. 42: 142-154.

Fawley, M.W., FAwley, K.P. \& Buchheim, M.A. (2004): Molecular diversity among communities of freshwater microchlorophytes. - Microb. Ecol. 48: 489-499.

Fenchel, T., Esteban, G.F. \& Finlay, B.J. (1997): Local versus global diversity of microorganisms: cryptic diversity of ciliated protozoa. - Oikos 80: $220-225$.

Fenchel, T. \& Finlay, B.J. (2004): The ubiquity of small species: patterns of local and global diversity. - BioScience 54: 777-784.

FINLAY, B.J. (2002): Global dispersal of free-living microbial eukaryote species. - Science 296: 1061-1063.

Finlay, B.J. \& Fenchel, T. (2002): Microbial eukaryote species. Science 297: 337.

FoIssner, W. (2006): Biogeography and dispersal of micro-organisms: A review emphasizing protists. - Acta Protozool. 45: 111-136.

FoIssner, W. (2008): Protist diversity and distribution: some basic considerations. - Biodiv. Conserv. 17: $235-242$.

Hegewald, E., Krienitz, L. \& Schnepf, E. (1994): Studies on Scenedesmus costato-granulatus Skuja. - Nova Hedwigia 59: 97-127.

Hepperle, D. \& Krienitz, L. (2001): Systematics and ecology of chlorophyte picoplankton in German inland waters along a nutrient gradient. - Internat. Rev. Hydrobiol. 86: 269-284.

Hillebrandt, H., Watermann, F., Karez, R. \& Berninger, U. (2001): Differences in species richness patterns between unicellular and multicellular organisms. - Oecologia 126: 114124.

HiNDÁK, F. (1988): Studies on the chlorococcal algae (Chlorophyceae). IV. - Biologické Práce 34: $1-263$.

Hoshina, R., Kato, Y., Kamako, S.I., \& Imamura, N. (2005): Genetic evidence of 'American' and 'European' type symbiotic algae of Paramecium bursaria Ehrenberg. - Plant Biol. 7: 526-532.

Huber-Pestalozzi, G. (1929): Das Plankton natürlicher und künstlicher Seebecken Südafrikas. - Verh. 
Internat. Ges. Limnol. 4: 343-390.

Huss, V. A. R., Frank, C., Hartmann, E. C., Hirmer, M., Kloboucek, A., Seidel, B. M., Wenzeler, P. \& Kessler, E. (1999): Biochemical taxonomy and molecular phylogeny of the genus Chlorella sensu lato (Chlorophyta). - J. Phycol. 35: 587598.

Huelsenbeck, J.P. \& Ronquist, F. (2001): MrBayes: Bayesian inference of phylogenetic trees. Bioinformatics 17: 754-755.

JoвB, G. (2008): Treefinder, version of October 2008. Munich, Germany. Distributed by the author at www.treefinder.de.

KomÁreK, J. (1983): Contribution to the chlorococcal algae of Cuba. - Nova Hedwigia 37: 65-180.

KomÁrek, J. \& FotT, B. (1983): Chlorophyceae (Grünalgen) Ordnung: Chlorococcales. - In: Huber-Pestalozzi, G. (ed.) Das Phytoplankton des Süßwassers 7. Teil, 1. Hälfte. - 1044 pp., Schweizerbart'sche Verlagsbuchhandlung (Nägele u. Obermiller), Stuttgart.

KomÁrek, J. \& Perman, J. (1978): Review of the genus Dictyosphaerium (Chlorococcales). Arch. Hydrobiol. 51/Algological Studies 20: 233-297.

Kotut, K., Ballot, A., Wiegand, C. \& Krienitz, L. (2010): Toxic cyanobacteria at Nakuru sewage oxidation ponds - A potential threat to wildlife. - Limnologica 40: 47-53.

KRIENITZ, L. \& Bock, C. (2011): Elongatocystis ecballocystiformis gen. et comb. nov., and some reflections on systematics of Oocystaceae (Trebouxiophyceae, Chlorophyta). - Fottea 11: 271-278.

Krienitz, L., Bock, C., Luo W. \& Pröschold, T. (2010): Polyphyletic origin of the Dictyosphaeriummorphotype within Chlorellaceae (Trebouxiophyceae). - J. Phycol. 46: 559-563.

Krienitz, L., Bock, C., Dadheech, P.K. \& Pröschold, T. (2011): Taxonomic reassessment of the genus Mychonastes (Chlorophyceae, Chlorophyta) including the description of eight new species. - Phycologia 50: 89-106.

Krienitz, L., Hegewald, E.H., Hepperle, D., Huss, V.A.R., Rohr, T. \& Wolf, M. (2004): Phylogenetic relationship of Chlorella and Parachlorella gen. nov. (Chlorophyta, Trebouxiophyceae). - Phycologia 43: 529-542.

Krienitz, L., TakedA, H. \& Hepperle, D. (1999): Ultrastructure, cell wall composition and phylogenetic position of Pseudodictyosphaerium jurisii (Chlorococcales, Chlorophyta) includingacomparisonwithotherpicoplanktonic green algae. - Phycologia 38: 100-107.

KrienitZ, L. \& WirTh, M. (2006): The high content of polyunsaturated fatty acids in Nannochloropsis limnetica (Eustigmatophyceae) and its implication for food web interactions, freshwater aquaculture and biotechnology. Limnologica 36: 204-210.

Logares, R.E. (2006): Does the global microbiota consist of a few cosmopolitan species? - Ecol. Austral. 16: 85-90.

Luo, W., Pflugmacher, S., Pröschold, T., Walz, N. \& KRIENITZ, L. (2006): Genotype versus phenotype variability in Chlorella and Micractinium (Chlorophyta, Trebouxiophyceae). - Protist 157: 315-333.

Luo, W., Pröschold, T., Bock, C. \& Krienitz, L. (2010): Generic concept in Chlorella-related coccoid green algae (Chlorophyta, Trebouxiophyceae). - Plant Biol. 12: 545-553.

Marin, B., Palm, A., Klingberg, M. \& Melkonian, M. (2003): Phylogeny and taxonomic revision of plastid-containing euglenophytes based on SSU rDNA sequence comparisons and synapomorphic signatures in the SSU rRNA secondary structure. - Protist 154: 99-145.

Müller, J., Friedl, T., Hepperle, D., Lorenz, M. \& DAY, J.G. (2005): Distinction between multiple isolates of Chlorella vulgaris (Chlorophyta, Trebouxiophyceae) and testing for conspecificity using amplified fragment length polymorphism and its ITS rDNA sequences. - J. Phycol. 41: 1236-1247.

Norton, T.A., Melkonian, M. \& Andersen, R.A. (1996): Algal biodiversity. - Phycologia 35: 308-326.

PAdisÁk, J. (2009): The phycogeography of freshwater algae. - In: Likens, G. (ed.) Encyclopedia of Inland Waters, Vol. I. Elsevier Inc. Oxford, pp 219-223.

Potter, D., Lajeunesse, T.C., Saunders, G.W. \& ANDERson, R.A. (1997): Convergent evolution masks extensive biodiversity among marine coccoid picoplankton. - Biodiv. Conserv. 6: 99-107.

Pröschold, T., Darienko, T., Silva, P.C., Reisser, W. \& Krienitz, L. (2011): The systematics of „Zoochlorella“ revisited employing an integrative approach. - Environ. Microbiol. 13: 350-364.

Pröschold, T. \& Leliaert, F. (2007): Systematics of the green algae: Conflict of classic and modern approaches. - In: Brodie, J. \& Lewis, J. (eds.) Unravelling the Algae: The Past, Present, and Future of the Algae Systematics. Taylor and Francis, London, pp. 123-153.

Rindi, F., Allali, H.A., Lam, D.W. \& LóPez-Bautista, J.M. (2010): An overview of the biodiversity and biogeography of terrestrial green algae. - In: Rescigno, V. \&. Maletta, S. (eds.) Biodiversity Hotspots. Nova Science Publishers, pp. 105-122.

Slapeta, J., López-García, P. \& Moreira, D. (2006): Global dispersal and ancient cryptic species in 
the smallest marine eukaryotes. - Mol. Biol. Evol. 23: 23-29.

SwOFFord, DL (2002): PAUP* Phylogenetic analysis using parsimony (* and other methods). Version 4.0b10. - Sinauer Associates, Sunderland.

TaLLing, J.F. (1987): The phytoplankton of Lake Victoria (East Africa). - Arch. Hydrobiol., Beihefte Ergebn. Limnol. 25: 229-256.

Uhlmann, D. (1966): Beitrag zur Limnologie extrem nährstoffreicher Flachgewässer. II. PlanktonMassenwechsel. - Wiss. Z. KMU Leipzig, Math.-nat. Reihe 15: 373-423.
Uhlmann, D. (1967): Beitrag zur Limnologie saprotropher Flachgewässer. - Arch. Hydrobiol. 63: $1-85$.

Vanormelingen, P., Verleyen, E. \& Vyverman, W. (2008): The diversity and distribution of diatoms: from cosmopolitanism to narrow endemism. - Biodiv. Conserv. 17: 393-405.

(C) Czech Phycological Society (2012)

Received June 6, 2011

Accepted October 10, 2011 